NOTE TO USERS

This reproduction is the best copy available.

(B)

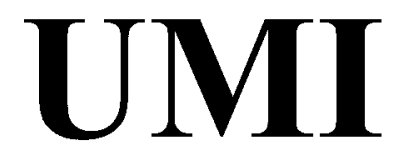




\title{
HAZARDOUS WASTE TRANSPORTATION: AN OVERVIEW
}

\author{
By \\ Muhammad Ashiq \\ B.E. (Civil), \\ NED University of Engineering and Technology \\ Karachi, Pakistan, 1987
}

\author{
A project \\ Presented to Ryerson University \\ in partial fulfillment of the \\ requirement for the degree of \\ Master of Engineering \\ in the Program of \\ Civil Engineering
}

Toronto, Ontario, Canada. 2003

(C) Muhammad Ashiq 2003 
UMI Number: EC52925

\section{INFORMATION TO USERS}

The quality of this reproduction is dependent upon the quality of the copy submitted. Broken or indistinct print, colored or poor quality illustrations and photographs, print bleed-through, substandard margins, and improper alignment can adversely affect reproduction.

In the unlikely event that the author did not send a complete manuscript and there are missing pages, these will be noted. Also, if unauthorized copyright material had to be removed, a note will indicate the deletion.

(®)

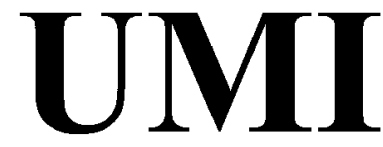

UMI Microform EC52925

Copyright 2008 by ProQuest LLC.

All rights reserved. This microform edition is protected against unauthorized copying under Title 17, United States Code.

ProQuest LLC

789 E. Eisenhower Parkway PO Box 1346

Ann Arbor, MI 48106-1346 


\section{AUTHOR'S DECLARATION}

I hereby declare that I am the sole author of this project.

I authorize Ryerson University to lend this project to other institutions or individuals for the purpose of scholarly research.

Muhammad Ashiq

Department of Civil Engineering

Ryerson University

I further authorize Ryerson University to reproduce this project by photocopying or by other means, in total or in part, at the request of other institutions or individuals for the purpose of scholarly research.

Muhammad Ashiq

Department of Civil Engineering

Ryerson University 


\section{Borrowers}

Borrowers undertake to give proper credit for any use made of the thesis. Ryerson University requires the signatures of all persons using or photocopying this project.

Please sign below and give address and date.

\begin{tabular}{|l|l|l|l|}
\hline Name & $\begin{array}{c}\text { Signature of } \\
\text { Borrower }\end{array}$ & Address & Date \\
\hline & & & \\
\hline & & & \\
\hline & & & \\
\hline & & & \\
\hline & & & \\
\hline & & & \\
\hline & & & \\
\hline & & & \\
\hline & & & \\
\hline & & & \\
\hline & & & \\
\hline & & & \\
\hline
\end{tabular}




\section{Ryerson University}

\section{School of Graduate studies}

The undersigned certify that they have read, and recommend to the School of Graduate Studies for acceptance, a project entitled "Hazardous Waste Transportation: An Overview" submitted in partial fulfillment of the requirements for the degree of Master of Engineering.

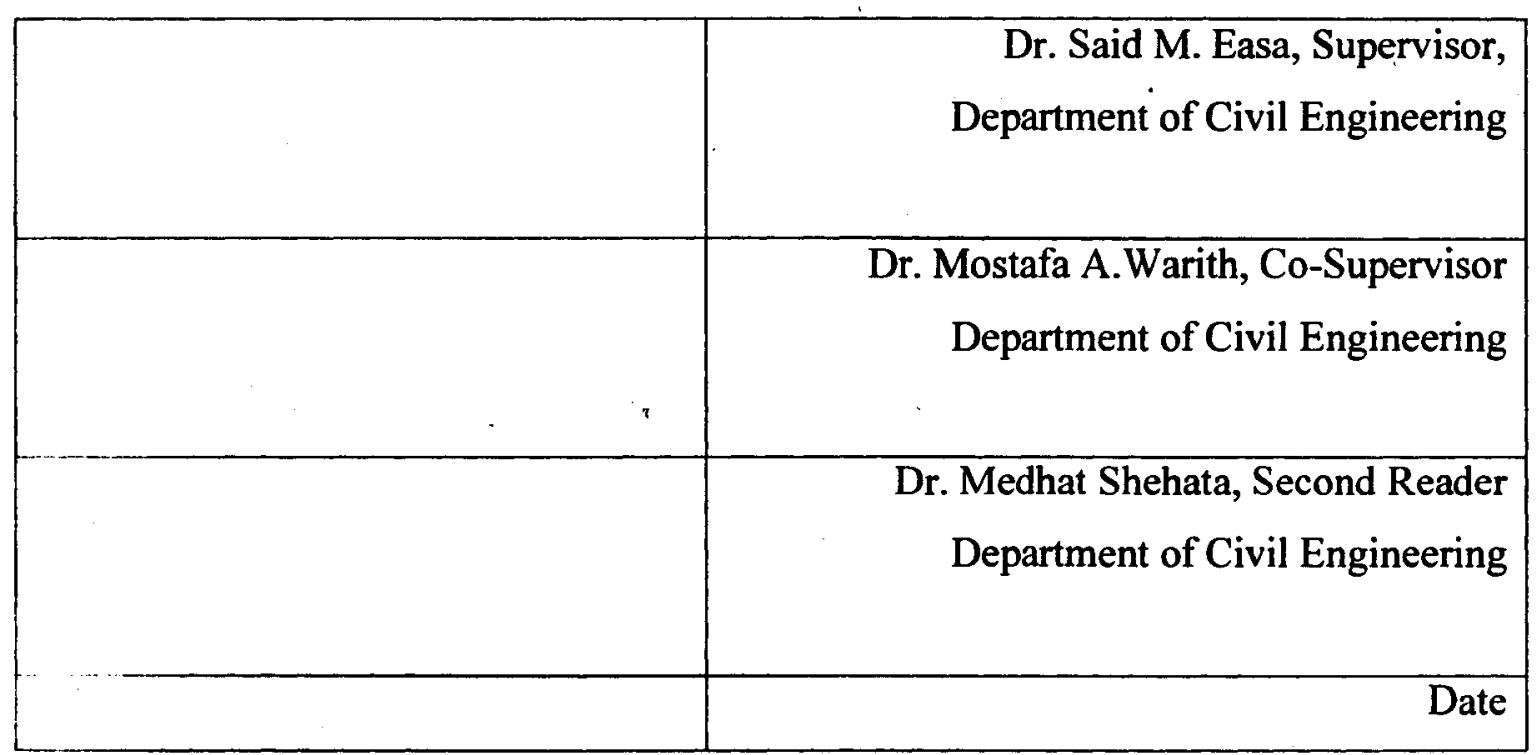




\title{
Hazardous Waste Transportation: An Overview
}

\author{
Muhammad Ashiq \\ Master of Engineering, 2003 \\ Department of Civil Engineering \\ Ryerson University
}

\begin{abstract}
Increasing industrialization and globalization has spawned the unprecedented generation of environmental toxic and hazardous wastes. The existence of publicly known hazardous waste problems such as toxic spills, and river pollution that pose serious and very real threats to human health puts extensive pressure on the government to take an aggressive role in hazardous waste control and transportation. The main objective of hazardous waste transportation is public safety. Each government has the responsibility to ensure that hazardous materials should be transported safely for the sucial and economic good of the country. Hazardous waste management is now a major and urgent global concern. Various techniques, models, and guidelines for the perception of risks associated with the transport of the hazardous materials are developed. Database of the accident data are developed by transportation agencies to be used for the development of models to improve safety of hazardous waste transportation. Based on the available risk perception models, accident models, the type of hazardous material, origin/destination, and the availability of emergency response routes for their transport
\end{abstract}


are properly designed. Advanced technologies, automated vehicle location system (AVL) and geographical information system (GIS) are also used for the analysis and modeling for the safe transport of hazardous materials. The purpose of this project is to present a literature review of hazardous waste materials and their impact on human health, regulations to control the movement of hazardous materials, Basel Convention and its effectiveness, treatment and disposal of hazardous materials, model developments for risk perception and management and the use of advanced technologies for safe transportation of hazardous wastes. Based on the literature review, the conclusions and future recommendations for possible improvement of the models and techniques used for safe transportation of hazardous wastes are presented. 


\section{ACKNOWLEDGMENTS}

I would like to thank my project supervisors Dr. Said M. Easa, Dr. Mostafa A. Warith for their outstanding supervision and guidance. Their support, advice and constructive criticism through my graduating have been invaluable.

I feel honor to say thanks to Dr. Medhat Shehata and Dr. Amleh Lamya for their continuous guidelines and encourage throughout my studies.

I am also grateful to my brothers, sister, dear wife and children for their continued support, pray and love. Special thanks to my friend Atif Mahmood for his continued support during my study. I am also grateful to my all colleagues at Ryerson University for their moral and technical support.

Deepest gratitude to my wife and kids, who had to sacrifice their needs and time and supported me to finish my studies,

Finally, I am grateful to the Grace of God for the countless blessings I have received. 


\section{DEDICATION}

Dedicated to my loving parents.

viii 


\section{Table of Contents}

Abstract

Acknowledgement

v-vi

List of Figures

vii

List of Tables

xii

xiii

Chapter 1 INTRODUCTION

1.1 Purpose and Scope of Project

Chapter 2 HAZARDOUS WASTES AND ITS IMPACT ON HUMAN HEALTH

2.1 Introduction

2.2 Hazardous Wastes

2.2.1 Ignitability

2.2.2 Corrosivity 7

2.2.3 Reactivity 7

2.2.4 Toxicity , 7

2.3 Generation of Hazardous Wastes 8

2.3.1 Hazardous Wastes Generated by Industrial Activity 8

2.3.1.1 Mining Industry $\quad 8$

2.3.1.2 Oil and Gas Exploration 9

2.3.2 Hazardous Wastes Generated by Businesses 10

2.3.2.1 Vehicle and Equipment Repair, Transportation and Cartage 10

2.3.2.2 Building and Road Construction, Renovation $\begin{array}{ll}\text { and Maintenance } & 10\end{array}$

$\begin{array}{lll}\text { 2.3.2.3 Manufacturing } & 10\end{array}$

2.3.2.4 Printing, Publishing and Photo Finishing 11

2.3.2.5 Dry Cleaning 11

2.3.3 Hazardous Wastes Generated by Community Activity 12

$\begin{array}{lll}2.3 .3 .1 \text { Education } & 12\end{array}$

2.3.3.2 Health and Dental Care 13

2.3.3.3 Power Production and Communication 13

2.3.3.4 Household Activities $\quad 13$ 
2.4 Hazardous Wastes Impact on Human Health 14

2.5 Hazardous Wastes a Real Problem 14

2.6 Hazardous Wastes and New Generation 16

$\begin{array}{ll}2.7 \text { Health Hazardous Categories } & 17\end{array}$

Chapter 3 HAZARDOUS WASTE MANAGEMENT IN CANADA 19-36

$\begin{array}{lll}3.1 & \text { Introduction } & 19\end{array}$

3.2. Management of Hazardous Waste in Canada 19

3.3 Import/Export of Hazardous Wastes in Canada 12

3.3.1 Federal Regulations $\quad 24$

3.4 Hazardous Waste Management in Ontario 25

3.4.1 Pre-Treatment Standards $\quad 26$

3.4.2 Destruction of Wastes 26

3.4.3 Hospital Incinerators 27

3.4.4 Destruction Technologies for Hospital Wastes 28

3.4.5 Regulations in Ontario 29

3.4.6 Past Initiatives in Regulations 30

3.4.7 Prospective Initiatives in Regulations 32

3.5 Canada US Agreement 33

3.5.1 Compatibility with Basel Convention 34

Chapter 4 EVOLUTION OF THE BASEL CONVENTION 37-46

4.) Introduction 37

$\begin{array}{lll}4.2 & \text { Background of Basel Convention } & 37\end{array}$

4.3 Implementation of Basel Convention 38

4.4 Importance of Basel Convention 40

4.5 The Vital Goal of Basel Convention 41

4.6 An Overview of Compliance and Enforcement 42

4.6.1 The Control System for the Movement of Hazardous Waste 43

4.6.2 National Reporting of Hazardous Wastes 43

4.6.3 Technical Assistance Offered by the Convention 44 
4.6.4 Training in the Management and Minimization of Hazardous Wastes 44

4.7 Milestones in the Convention's History 45

Chapter 5 HZARDOUS WASTE TRANSPORTATION 47-63

$\begin{array}{lll}5.1 & \text { Introduction } & 47\end{array}$

5.2 Modes of Transportation $\quad 47$

5.2.1 Highway Transport 48

5.2.2 Rail Transport 49

5.2.3 Water Transport $\quad 50$

5.2.4 Air Transport $\quad 51$

5.2.5 Pipeline Transport _. 51

5.3 Risk Management in Hazardous Waste Transport 52

5.4 GIS and Transportation $\quad 56$

5.4.1 GIS Applications in Routing Planning 57

5.4.2 GIS Risk Analysis of Hazardous Materials Transport 58

5.5 Use of Advanced Technologies for Improving Hazmat Transportation Safety 60

Chapter 6 CONCLUSIONS AND RECOMMENDATIONS 64-68

6.1 Cunclusions 64

5.2. I uture Recommendations 66

$\begin{array}{ll}\text { REFERENCES } & 69-73\end{array}$

$\begin{array}{lll}\text { APPENDIX: A } & \text { 74-78 }\end{array}$ 


\section{LIST OF FIGURES}

Figure 3.1 Statistics on export and import of hazardous waste from 1991-2001

Figure 3.2 Canadian Imports by Disposal and Recycling Operation in 2001

Figure 3.3 Ontario Imports by Disposal and Recycling Operation in 2001

Figure 3.4 Quebec Imports by Disposal and Recycling Operation in 2001 


\section{LIST OF TABLES}

Table 2.1 ASTDR Public Health Hazard Categories

18

xiii

Reproduced with permission of the copyright owner. Further reproduction prohibited without permission. 


\section{CHAPTER 1}

\section{INTRODUCTION}

Most Canadian and American federal and other States define "hazardous waste" as any waste or combination of wastes in solid, liquid, semisolid, or contained gaseous due to its quantity, concentration or physical, chemical, or infectious characteristics may cause or significantly contribute to an increase in mortality or an increase in serious irreversible or incapacitating reversible, illness or pose a substantial present or potential hazard to human health or to the environment when improperly treated, stored, treated, transported, or disposed of or otherwise managed.

The danger posed by hazardous waste to human life, health, property and the environment have been of great concern to the public in recent years. Generally everyone agrees that there must be disposal sites for hazardous waste somewhere. But no one wants these sites located near where they live and work. Therefore ever-increasing hazardous wastes generated by industrial society are transported to few disposal sites available at great distances. For example, every two weeks a truck loaded with radioactive waste departs from New England Nuclear Corporation in Boston bound for a nuclear waste dump across the country in the State of Washington, a distance of 2,890 miles (Stephen 1983). As more hazardous wastes are transported to greater distances, the probability of accidents and spills will naturally increase.

The highway transport mode is regarded as the most versatile. Tank/trucks can access the most industrial sites as well as treatment, storage and disposal facilities. While the railway shipping requires expensive sidings and is suitable only for the large quantity of shipments. Cargo tanks are main carriers of bulk hazardous materials, however large 
quantities of hazardous wastes are shipped in 55 gallons drums. They range in capacity from about 2000-9000 gallons depending on the road weight laws. Hazardous waste materials transportation accidents tend to be spectacular, dangerous and unpredictable. Accidents involving truck shipment of hazardous materials occurring in the urban area are more likely to endanger human lives and property.

In transportation there is little distinction between hazardous waste and hazardous materials. Both are deleterious substances capable of causing injury or environmental damage if not properly managed in the transportation system. The responsibility for ensuring the public safety in the movement of hazardous waste is shared by the transporters, the shippers and the government agencies. Each plays an important role in dealing with the issues, and if they fulfill their obligation, will result in safe effective transportation of hazardous waste.

In order to avoid accidents in the transportation of hazardous wastes their movements are subjected to considerably more regulatory control. Much of the regulatory focus has shifted to accident prevention, emergency response activity, and surveillance of import/export activity, safe route design and tracking of wastes from source to ultimate disposition (Eugene 1990).

There has been significant increase in the dumping of the imported hazardous waste in Ontario (Ministry of Environment 2001). There are numerous factors for this increase; however, the most significant is the absence of proper restriction on the land disposal. The situation requires an immediate action by the province. Increase in imports arises from increasingly strict disposal standards in the United States, and implementations of more relax standards in Ontario. In 1994, for example, a prohibition 
on the land disposal of untreated hazardous wastes was finalized under the US Resource Conservation and Recovery Act (RCRA). This ban flowed from amendments to the U.S. legislation adopted in 1984, following the Love Canal disaster in New York State in 1883.

Canada is a party to the Basel Convention on the Control of Trans-boundary Movements of Hazardous Wastes and their Disposal. Under Article 2(g) of the Convention, Parties are required to "prevent the import of hazardous waste and other wastes if it has reason to believe that the wastes in question will not be managed in an environmentally sound manner." Under international law, it is the Government of Canada, which is ultimately responsible to the international community for the fulfillment of this obligation.

There are no comparable standards for land combustion or disposal existed in Ontario until 2000. At the same time, the approvals process for hazardous waste disposal sites has been significantly weakened since 1995. This has occurred through a combination of legislative amendments and policy changes. The Ontario Ministry of the Environment has also suffered a significant loss of capacity to oversee the management of hazardous wastes, and other activities, which may pose a threat to human health or the environment, as a result of major budgetary reductions (Wilson et al. 2000).

In Canada there are three waste sites exclusively devoted to hazardous wastes. The Laid law's hazardous waste facility near Sarnia will contain 7.5 million tones when full (Wilson et al. 2000). In addition, municipal wastes generally contain about one percent of hazardous wastes, e.g. vinyl chloride, lead, arsenic and benzene, many of which are carcinogenic. A continually increasing population is challenging our 
environment's ability to absorb all these wastes, as demonstrated by increase in pollution level in the Great Lakes and the decline in fish stock.

The Philip Services Corporation at Taro landfill in Stoney Creek was approved as a "non-hazardous industrial waste" disposal site without a public hearing under the Environmental Assessment Act in July 1996 (Wilson et al. 2000). It was later discovered that the operator was importing hazardous wastes from the U.S., solidifying them with Portland cement, and disposing them as non-hazardous wastes in the landfill. The Ministry of the Environment was forced to take action to end this practice in September 1999 , after this practice was followed for several years.

The third site is Safety-Kleen Ltd. hazardous waste landfill near Sarnia, which was approved without a public hearing under the Environmental Assessment Act in September 1997 (Wilson et al. 2000). In November 1999 it was discovered that groundwater and methane were leaking into one of the new areas of the landfill, breaching the liner and raising the possibility of groundwater contamination. The facility was temporarily prohibited from receiving wastes for disposal in December 1999.

The danger from the hazardous wastes is posed by two factors: the material's inherent toxicity and its accessibility. By isolating the waste its accessibility is greatly reduced. Industry, from which we all benefit, must share responsibility for the increasing burden of wastes in our environment. Transportation is an obvious example with its contribution to urban smog, acid rain and global warming. The energy industry is no different: combustion of fossil fuels, coal, oil and natural gas, emits the hazardous gases to the environment. Coal also emits carcinogenic chemicals and heavy metals in ash, both to the atmosphere and in huge land based heaps. 
Generators, transporters and receivers of hazardous waste are subject to, and must comply with, detailed and exacting requirements and responsibilities. The liability exposure for anyone involved with hazardous waste is enormous. Compliance efforts must be a top priority. There is an absolute necessity to keep informed of the latest regulatory changes and interpretations. All parties should be certain that they are adequately insured, both as to amount and breadth of coverage.

\subsection{Purpose and Scope of Project}

The purpose of this project is to carry out a literature review of hazardous waste transportation practices and estimate possible environmental improvements if proper management techniques are used during handling and transportation of hazardous waste. This study will also focus on the following:

- Review of various hazardous waste materials and their impact on human health.

- Review of various regulation issues that are enforced to control the movement/transportation of hazardous waste materials. The review includes the Basel Convention and Canada-US agreement for the transportation of hazardous waste materials across the border.

- Discuss the development of hazardous materials database, risk assessment during their transport, management and the use of advance technologies for the safe movement of hazardous waste materials.

Based on the literature review, recommendations for the improvement of techniques used to manage and transport hazardous waste materials safely are presented. 


\section{CHAPTER 2}

\section{HAZARDOUS WASTES AND ITS IMPACT ON HUMAN HEALTH}

\subsection{Introduction}

The rapid industrialization without proper hazardous wastes disposal facilities, has not only polluted the global environment and the human health but also has posed a potential threat to the balance of ecosystem, which is pivotal to the sustainable development. This chapter will discuss various characteristics and categories of hazardous waste and how these affect the global environment specially the human health.

\subsection{Hazardous Wastes}

All countries, irrespective of their state of development, produce hazardous wastes. Examples of such ubiquitous wastes might include oils from transportation, redundant pesticides from agriculture, hospital wastes, waste from ship cleaning, chemical wastes from commerce, mercury from fluorescent lamps and batteries, acids and lead from recycling of motor batteries (Wilson and Balkau 1990). A waste is hazardous if it exhibits one or more of the following characteristics:

\subsubsection{Ignitability}

Ignitability is the characteristic used to define as hazardous those wastes that could cause a fire during transport, storage or disposal. Example of ignitable wastes includes waste oils and used solvents. 


\subsubsection{Corrosivity}

Corrosive wastes are acids or bases that are capable of corroding metal storage tanks or containers which may result in release of the material, or may injure persons who come in contact with it. Corrosivity, as indicated by $\mathrm{pH}$, was chosen as an identifying characteristic of a hazardous waste because wastes with high or low $\mathrm{pH}$ can react dangerously with other wastes or cause contaminants to migrate from certain wastes. Example of corrosive wastes includes acidic wastes and used pickle liquor from selected steel manufacture. Steel corrosion is a prime indicator of a hazardous waste since wastes capable of corroding steel can escape from drums and liberates other wastes (Wilson and Balkau 1990).

\subsubsection{Reactivity}

Reactive wastes are unstable under normal conditions. They can cause explosions, or release toxic fumes, gases or vapors when mixed with water. Examples of reactive waste include water from TNT operation and used cyanide solvents.

\subsubsection{Toxicity}

Toxic wastes are harmful or fatal when ingested or absorbed. When toxic wastes are disposed on land, contaminates may leach from the waste and pollute ground water or surface waters. Toxicity characteristic wastes are identified by concentration levels of contaminate that may be harmful to human health or the environment. This characteristic only identifies wastes, which contain certain specified contaminants. Listing them in regulations identifies other toxic wastes. 


\subsection{Generation of Hazardous Wastes}

Hazardous wastes are generated by different activities: industrial, business, community and household activities. The following sections provide the details of hazardous waste produced by each activity.

\subsubsection{Hazardous Wastes Generated by Industrial Activity}

There are two main industry groups that cause the production of hazardous wastes from their activities,

- Mining industry

- Oil and gas exploration

In most cases, these industries because of their remote locations, act as industries and small industrial communities or work camps. Thus, they generate both industrial and domestic wastes.

\subsubsection{Mining Industry}

The primary hazardous wastes generated by mining industry are acid solutions, spent solvents, alkali solutions, tank sludges, contaminated soil and sand, drilling mud, explosives, oils, wastes associated with equipment repair, and the construction (Reid and Pertners 1980, Thompson 1990). Wastes associated with equipment repair include: waste oil, acid batteries, antifreeze, cutting oil, and bulky wastes. Wastes associated with building maintenance and construction includes: resins, adhesives, paints, paint thinners, strippers and lacquers, and bulky wastes. 
Many mining wastes are placed in on-site disposal areas called tailings ponds. The treatment accomplished in tailings ponds includes: gravity settling, chemical oxidation or reduction, and ultraviolet breakdown of solids and liquids. Wastes treated in this manner are usually acids, alkalis, contaminated soil and sand, and drilling mud. Other wastes as obsolete explosives are detonated with fresh material in the extraction of ore stage. Used oil and spent solvents are either burnt or used for dust control and many other wastes are stored on site or disposed of at an on-site landfill.

\subsubsection{Oil and Gas Exploration}

Predominant wastes which are produced by oil and gas companies include: waste drilling fluid, alkaline solution, waste oil sludge, filters, oil spill debris, glycol, catalysts, and wastes from equipment, repair, and maintenance (Stanley 1986, Reid and Partners 1980, Canadian Petroleum Association 1984). Drilling mud is generated in a large quantity than the rest of these wastes (Lavalin 1984). It is needed in the drilling system to flush away broken rock, lubricate the bit, and maintain pressure that prevents fluids in the rock formation from flowing. Drilling mud is generally either discharged into receiving bodies or collected in a sump, where the water evaporates. The remaining sludge is land farmed. Treatment methods used for other wastes include: waste oil sludge, recycled or treated to remove soil and sand, spread on roadways or burnt off. Filters burnt or disposed of in landfill sites and other wastes, generally taken to on-site or municipal landfill sites. 


\subsubsection{Hazardous Wastes Generated by Businesses}

\subsubsection{Vehicle and Equipment Repair, Transportation and Cartage}

This group of business includes more businesses than any of the others. Hazardous wastes generated by these facilities are: waste oil, fuel tank sludges, spent solvents, acid batteries, waste paint, anti-freeze, paint thinner, windshield washer fluid, contaminated fuels, resins, and adhesives (Stanley 1986, Reid and Partners 1980, Technology Resources 1989). These wastes may be produced in small quantities by each generator but are substantial, collectively. Most of these wastes are either spread on roadways, burned off or dumped into municipal sewers, landfill sites or elsewhere.

\subsubsection{Building and Road Construction, Renovation and Maintenance}

This group includes businesses involved in construction, lumber, painting, and glass, wood and concrete products. This is the next largest group. Their wastes are: waste paint, resins and adhesives, waste paint thinner, waste tar and residues, primers and sealers, asbestos, strippers and lacquers, cutting oil, spent solvents, and wood preservatives (Reid, Crowther and Partners Limited 1980, Technology Resources Inc. 1989, Alaska Department of Environmental Conservation 1986). Most of these wastes are disposed of in municipal sewers and landfill sites.

\subsubsection{Manufacturing}

This group consists of metal fabrication, machine shops, and ship and boat building. Wastes produced by this category include: waste paints and paint thinner, spent solvents, machining wastes, cutting oil, resins and adhesives, and metal finishing 
solutions. Most of these wastes are disposed of in municipal sewers and landfill sites or private landfills (Reid and Partners 1980, Technology Resources 1989).

\subsubsection{Printing, Publishing and Photo Finishing}

These businesses produce wide range of toxic by products (Deyle 1989). Printing and publishing wastes include: spent solvents, ammonia for blue print machines, copy machine chemicals, waste ink, and ink sludge. Photo-finishing generates: waste fixers, waste developers, ferricyanide bleach, and bleach-fix solutions. These waste solutions and sludges may contain silver and are sometimes recycled to recover this metal (Alaska 1986). Their chemicals are toxic. If not recovered or reused photo finishing wastes generally end up in municipal sewers or landfills.

\subsubsection{Dry Cleaning}

There are four commonly used substances in the dry cleaning business: perchloroethylene (PCE), petroleum solvents (Deyle 1989, Technology Resources 1989). PCE is harmful to the liver and kidneys in humans if swallowed. It may also be carcinogenic. Used petroleum solvents can cause nausea, vomiting, coughing, and lung irritation. Hazardous wastes generated by the dry cleaning industry, irrespective of the solvent used, include: (Technology Resources Inc., Deyle 1989, Raymond 1990) waste solvent, still residues, spent filter cartridges, cooked powder residues, drained filter residues, and oil and grease sludge contaminated with heavy metals. Most operations are equipped with stills to recover cleaning solvents; very small plants without stills probably discharge waste solvent directly to the sewer (Technology Resources Inc. 1989). The still 
residues and solvent filtration cartridges contain small fractions of solvent as well as waste grease, oil and dirt. Most solid residues and cartridges are picked up by the local garbage disposal and are land filled. Sometimes these wastes are taken out of the states for proper disposal.

\subsubsection{Hazardous Wastes Generated by Community Activity}

Hazardous wastes are generated, in small quantities, by routine community activities. Activities which generate hazardous wastes in communities include: building construction and road maintenance, vehicle and equipment repair and maintenance, education, health and dental care, power production and communication, and household activities. Wastes generated by building construction and road maintenance and vehicle and equipment repair and maintenance are already discussed. A recent study (Heinke and Wong 1990) revealed domestic waste generation rates of $0.013-0.015 \mathrm{~m}^{3} /$ person/day of un-compacted wastes in the three communities studied. If construction activities are substantial in a community these rates can be as high as $0.017 \mathrm{~m}^{3} / \mathrm{person} /$ day. The wastes generated by other communities are described in the following subsequent sections.

\subsubsection{Education}

Secondary and post-secondary educational institutions often incorporate chemical laboratories, which may contribute to the hazardous waste problem. Most labs store a large variety of toxic substances that must eventually be disposed of, used or unused. Other wastes produced by educational facilities are biological wastes, photo-finishing wastes, cleaning solvents and solutions and wastes involved with machine, auto body, 
and carpentry shops. In general, these substances end up in sewers, landfills or are stored on site indefinitely.

\subsubsection{Health and Dental Care}

This group includes nursing stations, hospitals, dental clinics, veterinary clinics and funeral services (Reid and Partners 1980, Thompson 1990, Carpenter 1990). These facilities generate a variety of infectious or otherwise toxic wastes including: disposables used in medical practice, anatomical wastes, sharps, out of date medication, discarded mercury thermometers, X-Ray developing fluid, disinfectants, waste formaldehyde, and animal carcasses. The carcasses of euthanized animals are of particular concern. Not only could a carcass be carrying a disease but could also contain significant quantities of a deadly drug. If improperly disposed of, animals or birds may feed on the carcass and be harmed.

\subsubsection{Power Production and Communication}

The places where power is supplied by both hydroelectric and diesel generators, the wastes include: contaminated fuel, fuel tank bottoms, used oil, maintenance chemicals, asbestos, mercury, empty gas cylinders, acid batteries, and flammable wastes (Reid and Partners 1980, Heifrick 1990).

\subsubsection{Household Activities}

The largest quantity of hazardous wastes generated in households all over the world is human sewage. Many communities are serviced with bagged sewage (honey 
bags) or pump-out sewage systems. Some of these communities do not have adequate methods of disposing of these wastes. In some cases, honey bags and pump-out sewage are merely discarded in the landfill site. Few dumps in the Arctic (regions where no mean monthly temperature is greater than 10 degree centigrade) are free from human and animal scavenging. The health hazards of this situation are evident. Other household hazardous wastes are produced in any developed region (Environment Canada 1988). They include: household cleaners, pesticides, herbicides, expired pharmaceuticals, drain and oven cleaners, paints and paint thinners, nail polish remover, bleach, lighter fluid, hair spray, shoe polish, glues, bulky wastes, and various other wastes. In most cases, these wastes end up in landfills, metal dumps or sewers.

\subsection{Hazardous Wastes Impact on Human Health}

Hazardous wastes are wastes that have the potential to harm humans or the environment, in either the short or long term. They impact on human health in many ways. The impacts may lead to disability or loss of life. Various hazardous wastes along with their impacts on human health are discussed in Appendix A.

\subsection{Hazardous Wastes a Real Problem}

Increasing industrialization and globalization have spawned the unprecedented generation of environmental toxic and hazardous wastes. Hazardous waste management is now a major and urgent global concern. Far more controversial is the issue about the significant quantities of wastes from the worlds' developed nations being shipped to developing countries in Asia, Africa and other parts of the world. The existence of 
publicly known hazardous waste problems such as toxic spills, and river pollution that pose serious and very real threats to human health puts extensive pressure on the government to take an aggressive role in hazardous waste control.

Sometimes industries are built in the middle of city, which are like ticking bombs. In India, Union Carbide and Bhopal explosion is an example of these situations. Several people lost their eyesight. Some got cancers. Mothers are giving birth to deformed babies. People were not given proper attention.

Another disaster is the Chernobyl Nuclear power plant accident in Russia where several neighboring countries also got affected. Recent footage shown on CNN documentary revealed that the ill effects of that accident are still haunting the neighboring region. Disable people, deformed babies, various unknown disease are very common in this area surrounding the Chernobyl Nuclear power plant.

These two incidents are examples of several accidents, which happened due to negligence in the industry. But these accidents showed that the hazardous waste problem is not limited to just one country. These accidents can become an international issue in which several countries can get affected. Last year, oil spill near Spain seashore by an oil tanker made a big dispute between the ship owners and Government of Spain. Spain was insisting that since this ship is not theirs so the owner of the ship or the country where it was coming from should pay the cost of cleaning. But after the intervention of tinvironmental Agencies this was settled and Spain cleaned the beach and shared the cost of cleaning of oil spill. 


\subsection{Hazardous Wastes and New Generation}

In the last 50 years, more than 75,000 new chemicals have been introduced into the environment. Health experts are increasingly concerned about the role chemicals may play in childhood diseases. Asthma, for example, has tripled in the 1980 s. Over the last 20 years, childhood cancer rates have increased by 10 percent. Neurodevelopment delays and possibly endocrine disruption are the worst ill effects of environmental threats to the health of children. A child's exposure to the environment begins in the womb and continues throughout the life course. Whether or not a child develops to attain his or her full potential depends on the very environment where he lives, learns and plays (Barry 1999). The basic tenet in understanding children's health is the fact that "a child is not a small adult".

A child's unique susceptibility to toxins in the environment arises from several conditions. Children undergo rapid growth and development and their delicate developmental processes are easily disrupted. Children have more future years of life than do most adults and thus have more time to develop any chronic diseases that may be triggered by early exposure to an unhealthy environment. Children have greater exposures to environmental toxins on a kilogram per kilogram basis since they eat more food and drink more fluid, and breathe more air with twice as much resting air intake than adults. They have immature metabolic pathways (especially in the first month after birth) and their hand-to-mouth behavior, worsened by their playing close to the ground. A report from the Natural Resource Defense Council showed that lead, air pollution, pesticides, environmental tobacco smoke and water contamination are the five worst environmental threats to the health of children. 


\subsection{Health Hazardous Categories}

The Agency for Toxic Substances and Disease Registry (ATSDR) classified the health hazard posed by individual uncontrolled hazardous waste sites in six categories (Table 1). A site is assigned one of these categories on the basis of professional judgment, using weight-of-evidence criteria; the assignments are not risk-based derivations. ASTDR's site categories differ from EPA's Hazard Ranking System for the same sites. For example, the EPA's ranking scheme takes into account ecological effects and environmental hazard; the ASTDR's scheme focuses solely on human health impact. By classifying sites according to human health hazard, the ASTDR is able to direct program resources and effort to those sites believed to present the greatest hazard to the public's health. Some EPA regions use the ATDR's hazard categories to refine their priorities for site remediation.

Health departments and agencies use public health advisories to warn the public of imminent, serious threats to their health. A public health advisory may be issued, for instance, when a local water supply is find to be contaminated by biological or chemical agents under conditions that make the water unsafe for drinking. Public health advisories are intended to effect personal and institutional actions. In the contaminated drinking water example, persons would be advised to boil the water (microbiologic contamination) or forego the water (chemical contamination). Institutions like coal or state environmental groups would be expected to identify the source of contamination and eliminate it (Barry 1999). 
Table 1.1: ASTDR Public Health Hazard Categories (Barry 1999)

\begin{tabular}{|l|l|}
\hline Hazard Category & Description/Criteria \\
\hline $\begin{array}{l}\text { Urgent Public Health } \\
\text { Hazard }\end{array}$ & $\begin{array}{l}\text { This category is used for sites that pose urgent public health hazards as } \\
\text { a result of short-term exposures to hazardous substances. }\end{array}$ \\
\hline $\begin{array}{l}\text { Indeterminate Health } \\
\text { Hazard }\end{array}$ & This category is used for sites with incomplete information. \\
\hline $\begin{array}{l}\text { No Apparent Public } \\
\text { Health Hazard }\end{array}$ & $\begin{array}{l}\text { This category is used for sites where human exposure to contaminated } \\
\text { media is occurring or has occurred in the past but at levels below } \\
\text { those of health concern. }\end{array}$ \\
\hline $\begin{array}{l}\text { No Public Health } \\
\text { Hazard }\end{array}$ & \begin{tabular}{l} 
This category is used for sites that do not pose public health hazards. \\
\hline Unclassified
\end{tabular} \\
$\begin{array}{l}\text { This category is no longer used, but was used for sites with very few } \\
\text { data. }\end{array}$ \\
\hline
\end{tabular}




\section{CHAPTER 3}

\section{HAZARDOUS WASTE MANAGEMENT IN CANADA}

\section{$3.1 \quad$ Introduction}

This chapter presents the background of hazardous waste management in Canada. The 'Federal and Ontario' regulations are also discussed. The hazardous waste management in Canada is comprised of Federal and Provisional management. The Federal government controls the international movement of hazardous wastes and also amends the regulations to improve the system. The provisional management regulates and operates the waste management facilities. The statistics of import and export of hazardous wastes and their importance are also presented. The Ontario regulations and prospective amendments are also discussed in detail. The US-Canada agreement for the inter-country movement of hazardous wastes along with its compatibility with the Basel Convention is also discussed.

\subsection{Management of Hazardous Waste in Canada}

In Canada, the management of hazardous waste is a shared responsibility. The Ciovernment of Canada regulates international movements of hazardous wastes, while the provincial and territorial governments control generators, waste management facilities and transportation within their jurisdictions. The provinces and territories also have regulations that set out requirements for the operation of waste management facilities. One of the key elements of the Canadian federal regulatory process of hazardous waste management is the mechanism of multi-stakeholder consultation, by which governmental 
and non-governmental organizations, interested parties and businesses are permitted to comment on proposed policies and legislation at the draft stages.

Canada provides bilateral assistance through its Canadian International Development Agency and participates in many bilateral activities related to capacity building. Canada has Memoranda of Understanding on environmental cooperation with several countries and has undertaken various activities related to hazardous waste management. Internationally, Canada is a party to the Basel Convention, the OECD Council Decision on Trade in Recyclable Materials, and the Canada-USA Agreement dealing with Trans boundary Movement of Hazardous Wastes. Domestically, the Canadian Council of Ministers of the Environment (CCME) and its Hazardous Waste Task Group has undertaken work in the areas of harmonization of waste legislation, policies and programs on a national basis.

The Canadian market for hazardous waste management services is estimated at $\$ 2$ billion annually, and employs 4,000 to 5,000 people providing services in consulting, chemical analysis and operation of hazardous waste management facilities. A number of Canadian waste management firms offer specialized services and technologies for oil and gas extraction and delivery, electrical power generation, and pulp and paper manufacturing, to name a few. Several firms in British Columbia, Alberta, Ontario and Nova Scotia have developed considerable expertise in cleaning up oil-contaminated sites and marine oil spills. Other unique Canadian technologies treat specific chlorinated contaminants, heavy metals or oily sludge.

New Canadian hazardous waste technologies also help prevent pollution and reduce and recycle hazardous waste. As well, many Canadian environmental service 
firms offer site assessments and diagnostics using advanced instrumentation in preparation for site remediation. A few companies market specialized thermal, biological, phyto and chemical technologies for contaminated soil treatment. The ultimate goal is to eliminate all generation of hazardous waste. Until technology can reach a point where this is possible, steps must be taken to ensure that these wastes are properly managed. Minimizing volumes, reducing toxicity and diverting to recycling are all important steps in the right direction (Environment Canada 2001).

\subsection{Import/Export of Hazardous Wastes in Canada}

The Trans boundary movement of hazardous waste enables the use of disposal facilities on either side of the border, which in some cases reduces long distance transportation between facilities within one country. In many cases, Canadian wastes are exported to the U.S. because the capacity for disposal or recycling does not exist in Canada, such as waste fuel for energy recovery; catalysts destined for precious metal recovery and spent caustic (black liquor) from the pulp and paper industry.

Canada has strict regulations on the Trans boundary movement and transportation of hazardous wastes under the Canadian Environmental Protection Act, 1999. Total hazardous waste imports represent less than $10 \%$ of what is generated in Canada. However imports for disposal increased in 1994-2001 (Figure 2.1). In 2001, nearly $98 \%$ of Canadian imports came from the United States. All but 10 tones of Canadian exports were sent to the United States. The balance was exported to Belgium for recycling. 


\section{EXPORTS \& IMPORTS (TONNES)}

1991-2001

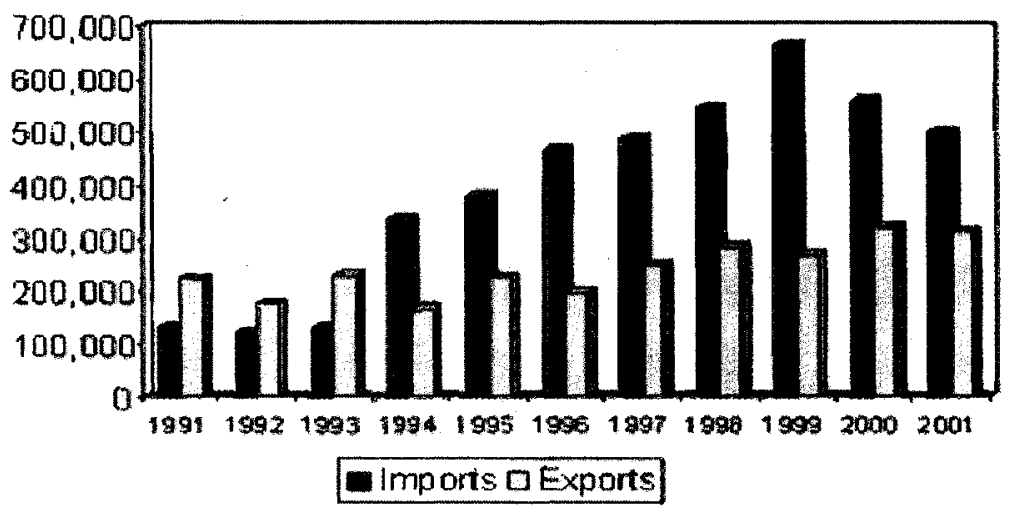

Figure 3.1: Statistics on export and import of hazardous waste from 1991-2001

(Environment Canada 2001)

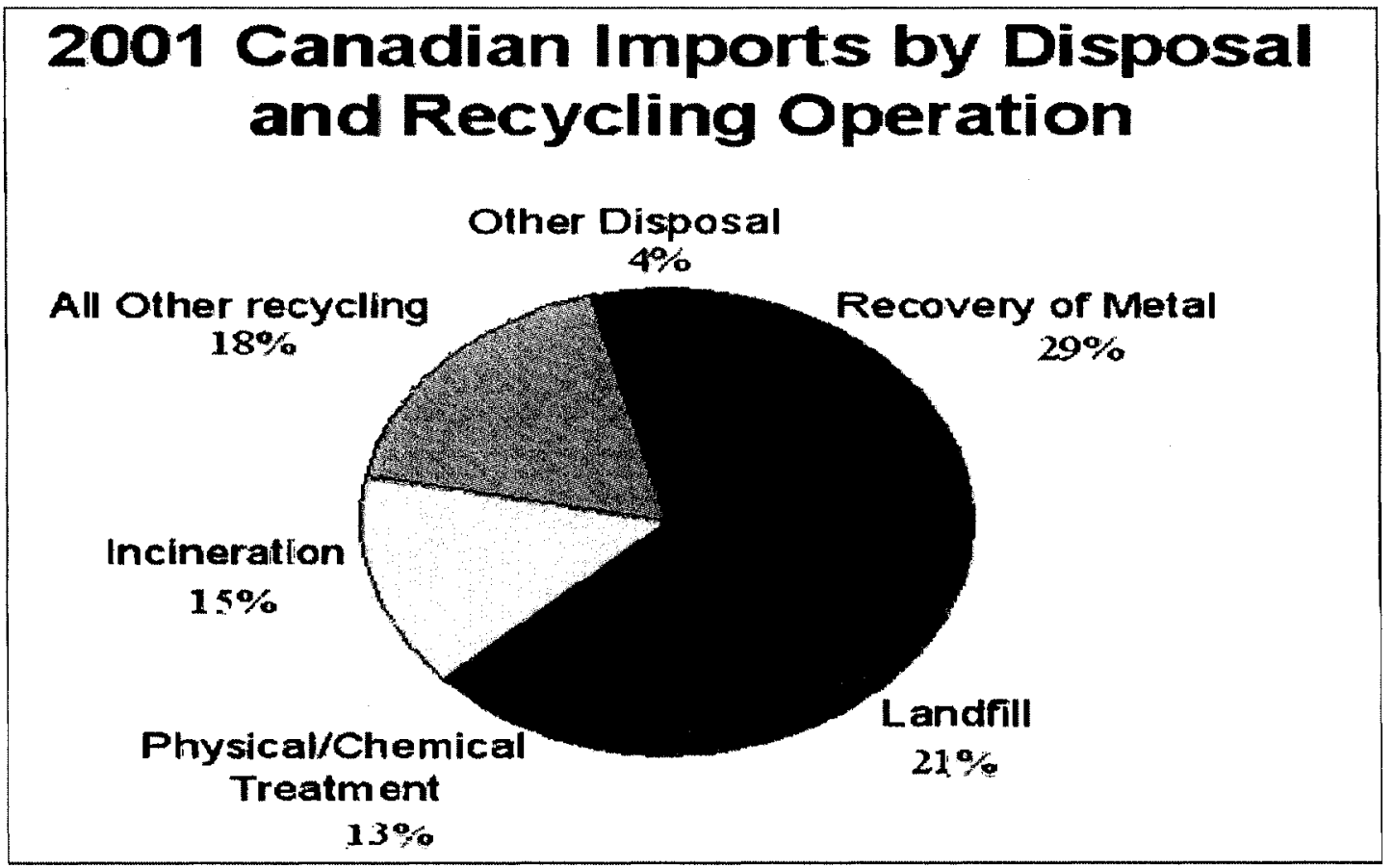

Figure 3.2: Canadian Imports by Disposal and Recycling Operation in 2001

(Environment Canada 2001) 
Shipments for recycling, which benefit Canadian industry and reduce reliance on primary resources, represent close to half of all imports. Batteries and metal-bearing wastes, such as shredded electronic scrap and mining residues, make up the majority of imports. Other hazardous waste imports include acids from metallurgical processes, contaminated soils and residues from oil refining (Figure 2.2). Imports of hazardous waste for recycling were destined to six provinces, but Ontario and Quebec continue to receive nearly all hazardous waste imports into Canada (Figures 2.3 and 2.4). More than 99.7\% of all imports for final disposal were destined for Ontario and Quebec, with very small quantities imported into British Columbia, Alberta and Manitoba. Total imports into Quebec are higher than those into Ontario. In both provinces over $46 \%$ of imports were destined for recycling.

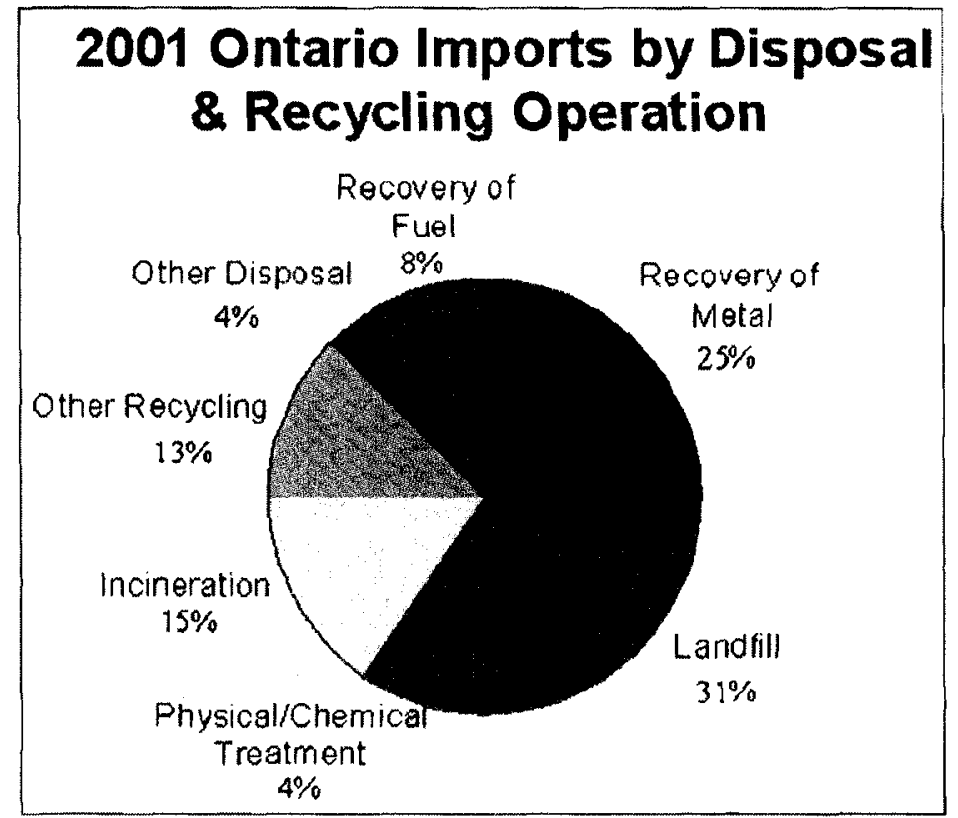

Figure 3.3: Ontario Imports by Disposal and Recycling Operation in 2001

(Environment Canada 2001) 


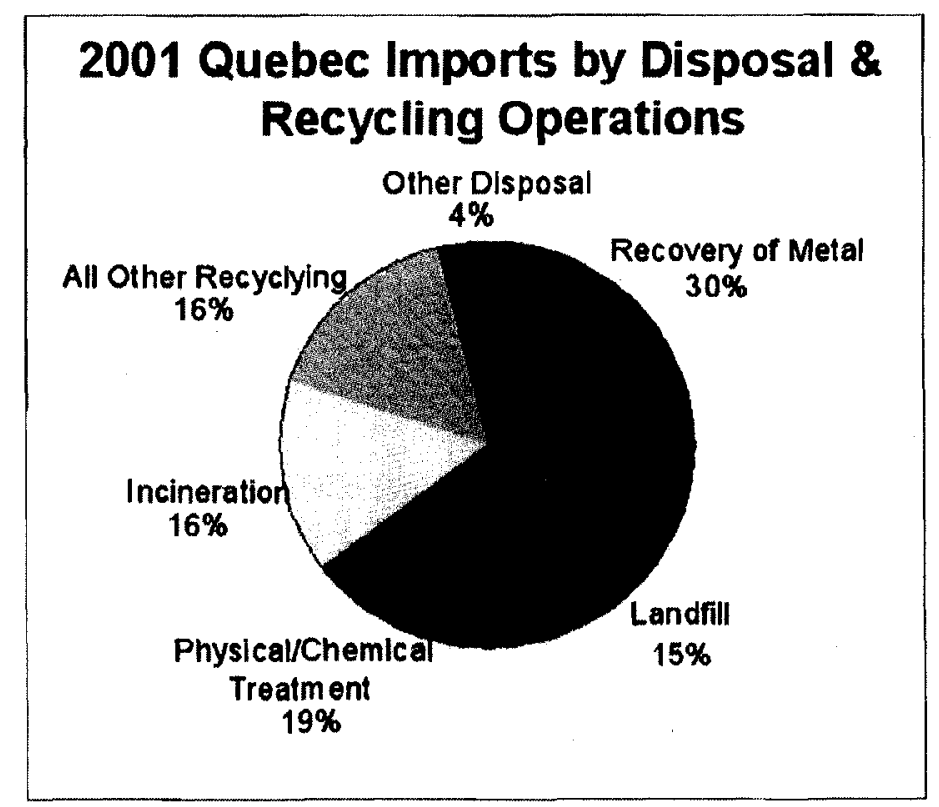

Figure 3.4: Quebec Imports by Disposal and Recycling Operation in 2001

(Environment Canada 2001)

Canadian exports between 2000 and 2001 decreased from 323,000 to 313,000 tonnes. Exports of hazardous waste for recycling originated from eight provinces, with Ontario and Quebec accounting for $76 \%$ of these shipments. The bulk of these shipments were managed by facilities in the Northeastern and Central United States. Waste from petroleum refining, the production of aluminum and the pulp and paper industry represent near half of all exports.

\subsubsection{Federal Regulations}

There are various regulations to regulate the import/export shipments and storage of the hazardous waste materials. The regulations are amended day by day to meet the present requirement of securing the common people from the threat of hazardous wastes. Federal Legislation Transportation of Dangerous Goods Act \& Regulations: provide a 
series of criteria and tests against which products to be shipped can be assessed to determine whether or not they are dangerous goods according to the regulations. Requirements are also prescribed for packaging and labeling of hazardous wastes to be shipped by road, rail, and marine or air (Environment Canada 2001). Export and import of hazardous wastes regulation provides legislation and controls for the import and export of hazardous wastes for the purpose of recycling and disposal. This regulation is written under the Canadian Environmental Protection Act (CEPA). The CEPA regulations also deal with the management of specific hazardous materials "PCBs". It is a useful guide to follow when establishing management procedures for the storage of any hazardous material. Polychlorinated biphenyls (PCBs) are a group of chlorinated compounds that have evidence of adverse environmental and human effect.

\subsection{Hazardous Waste Management in Ontario}

The Ontario government has introduced a comprehensive plan that will place Ontario among the world leaders in the management and reduction of hazardous wastes. The hazardous waste is managed under regulation 347 (General Waste Management) of Environmental Protection Act. EPA: regulates how all wastes, including hazardous wastes, are to be managed in Ontario and requires approval for transportation, processing and disposal of wastes. EPA Regulation 347 - General Waste Management: "Cradle to grave" management of hazardous and liquid industrial waste requires generators to register their facility and wastes generated with the MOE, to use registered carriers to ship their waste, to manifest their shipments, and to maintain records (Ministry of Environment 2001). 


\subsubsection{Pre-Treatment Standards}

The province is seeking input from the public and stakeholders regarding a proposal to establish pre-treatment requirements for hazardous wastes prior to land disposal. These standards are commonly referred to as land disposal restrictions, and are similar to those used in the United States. Land disposal restrictions prohibit activities that involve placing untreated hazardous wastes in or on the land. Under the proposal, hazardous wastes could not be disposed on land until the waste meets specific treatment standards to reduce the mobility or toxicity of its hazardous components.

Implementing these standards would further harmonize Ontario's hazardous waste management requirements with those of the U.S. The standards will reduce the amount of hazardous waste being imported into Ontario in order to avoid U.S. treatment requirements. These new rules would also act as a catalyst for Ontario's environmental industry to develop new technologies and new business 'opportunities as needed facilities are set up in Ontario to meet the new requirements.

\subsubsection{Destruction of Wastes}

There are approximately 99,000 tones of Polychlorinated biphenyls (PCBs) wastes in storage at 1,000 sites throughout Ontario. Some 7,000 tones are considered high-level (greater than 10,000 ppm), and 92,000 tones are considered low-level (less than 10,000 ppm). Until recently, there were few options available for destroying PCBs. More options now exist within and outside of Ontario, making the elimination of this waste possible. 
Eliminating Polychlorinated biphenyls (PCBs) wastes from storage will improve environmental protection by reducing the risk of toxic byproducts being released to the environment should a fire or other emergency occur at these sites. The elimination of these wastes over a three-year time frame set out in the regulation will also promote opportunities for Ontario's environmental industries to respond to the demand for Polychlorinated biphenyls (PCBs) destruction technologies. A timetable in the regulation will provide destruction dates for:

- PCBs currently in storage in sensitive sites,

- PCBs currently stored at all other sites, and

- PCBs coming out of service and into storage.

As part of the phase-out schedule, the ministry will require that all PCBs currently stored at sensitive sites such as schools ånd hospitals will be eliminated within one year of the regulation becoming law.

\subsubsection{Hospital Incinerators}

Each year in Ontario, about 10,000 tones of biomedical waste is generated and requires special management. This includes 2,000 tones of anatomical waste; 7,000 tones of non-anatomical waste (needles, glass, human and animal cultures); and 1,000 tones of pharmaceutical waste. Currently, 44 Ontario hospitals incinerate approximately 1,400 Iones of biomedical waste and 700 tones of municipal solid waste each year. The majority of the hospital incinerators currently in operation is over 20 years old and was not designed to handle the composition of biomedical waste currently being generated. 
These existing hospital incinerators will be phased out within one year of the proposed regulation taking effect. They are the 13 th largest emission source of mercury in Ontario, and the largest emission source of dioxins, accounting for about one-eighth of national emissions and one quarter of provincial emissions. In Ontario, there are three waste management firms that operate incineration and non-incineration technologies (autoclave and hydroclave technologies). These facilities have the capacity to manage the increased waste volumes when existing hospital incinerators close. Several Ontario hospitals have recognized cost savings from closing their incinerators and use alternative technologies for destruction of hazardous wastes.

\subsubsection{Destruction Technologies for Hospital Wastes}

Before choosing the destruction method, sources, weight and morphology of hazardous wastes generated should be identified. The collection and transported method should also be specified. A system should be put in place to control and segregate the generated waste into individual categories for further destruction by a proposed method. The world's most common technologies are sanitation based on steam or steam and vacuum and microwave sanitation (Rutala and Mayhall 1993). The destruction methods used are: steam sanitation, disinfection with superheated steam, hydroclave, dry heat disinfection, microwave sanitation, chemical disinfection, method of waste mineralization, method of waste sterilization with mineralization, and burying of sanitary waste (Citizens Environmental Coalition 1991, Pruss et al. 1999). The use of these methods has many advantages (Rutala and Mayhall 1993), including:

- Lower investment and operating costs 
- The environment not being burden with toxic products of incineration

- The waste remaining after remaining the destructive methods has properties of municipal waste

- It is possible to use mobile installations

- Economic and social security

- Easy handling and public acceptance

\subsubsection{Regulations in Ontario}

A further hazardous waste initiative that took effect on January 1, 2002, is an amendment to Ontario's waste regulation that requires hazardous waste generators to register annually, rather than on a one-time only basis. In addition, hazardous waste generators will be required to pay for the ministry's costs of managing hazardous and liquid industrial waste in the province. The amended regulation requires that each gemerator of liquid industrial and hazardous waste register annually with the Ministry of the Environment, providing more accurate and current information on the amount and yype of waste being disposed of both on- and off-site. Each generator is to pay a charge tor the annual registration: The charge will have the following three components,

- All generators must pay $\$ 50$ for each registered site

- All generators must pay $\$ 5$ for work associated with each manifest used to track the movement of waste off-site for treatment or disposal

- All generators must pay $\$ 10$ for each tone of hazardous waste disposed. 
The regulations will help offset nearly $\$ 12$ million of ministry's costs for managing hazardous waste. More than 16,000 hazardous waste generators will be affected. They include large waste management companies, power producers, chemical, oil and steel industries and municipal, provincial and federal governments. Annual registration will help keep an up-to-date picture of the amounts and types of hazardous wastes being produced and assist the ministry in developing policies to set reduction targets. The tonnage fees will also act as an incentive for companies to reduce the amount of hazardous wastes they generate.

Including as part of this initiative is the implementation of a new electronic hazardous waste information network (or HWIN), the first of its kind in North America. It will provide better service to generators and immediate up-to-date information on the generation, movement and disposal of hazardous waste. Online registration of hazardous waste generators is scheduled to begin on January 2, 2002, and be completed by mid February 2002.

\subsubsection{Past Initiatives in Regulations}

Over the past two years the government has introduced several new rules that make its hazardous waste requirements the toughest in Ontario's history. Since 1999, a number of changes to the hazardous waste regulations have made Ontario's hazardous waste standards more compatible with U.S. hazardous waste regulations, and the toughest in provincial history. These changes to the regulation have included: Implementing the next-generation leaching tests procedure, referred to as the Toxicity Characteristic Leaching Procedure (TCLP). This testing procedure determines whether a waste is likely 
to leach contaminants into groundwater at levels of concern. The new procedure is better at detecting organic contaminants and is tougher than the current U.S. Environmental Protection Agency (EPA) requirements. The Ontario procedure tests for 88 contaminants, while the U.S. procedure tests for 40 contaminants.

Updating Ontario's lists of hazardous waste to be compatible with those of the U.S. Adding a "derived from" rule similar to that of the U.S. EPA. This rule states that any listed hazardous waste will still be listed hazardous waste until it can be clearly demonstrated that it is no longer hazardous. Giving legal force to the ministry's Generator Registration Manual, which describes how to classify wastes. Adding a new "mixture rule" to ensure that, even if a listed hazardous waste is mixed with other substances, it will still be considered the same type of listed hazardous waste.

The Ontario government's Environmental Statute Law Amendment Act gave the ministry strong new legal powers to deter and punish illegal waste operators and others who choose to operate outside the law and threaten our environment. The legislation clused loopholes that enabled polluters to continue violating the law and avoiding penalties imposed on them. The law is fair to those who comply with environmental laws and lough on those who break them.

The province created an Environmental SWAT Team in the fall of 2000. This highly mobile unit dedicated to ensuring compliance with Ontario's environmental laws through tough, effective and fair enforcement. Working in partnership with the ministry's district offices, the team targets specific sectors of concern - those that have high noncompliance rates and/or may have significant impacts on public health and the environment. The inspections by the Environmental SWAT Team complement the 
significant number of inspections performed by ministry staff on a daily basis. This strong enforcement presence helps provide a higher level of environmental protection for the people of Ontario and helps level the playing field for Ontario businesses so that those who defy environmental laws do not benefit at the expense of those who comply.

Since its inception, the Environmental SWAT Team has completed more than 700 inspections in the following areas: pesticide applicators; septic waste haulers; hazardous, liquid industrial and solid waste haulers; hazardous waste transfer and processing facilities; electro/metal platters; and recycling in the industrial, commercial and institutional sectors.

\subsubsection{Prospective Initiatives in Regulations}

As part of its overall hazardous waste plan, the government intends to implement the following hazardous waste initiatives over the next two to three years:

- A pollution prevention program that will include specific reduction targets for hazardous wastes; a technical assistance program to help industry reduce their hazardous waste; diversion programs for used oil, electronic equipment, fluorescent tubes and special household wastes; and requirements for specific industries to develop pollution prevention plans.

- A new legislative framework for wastes and recyclables to foster increased recycling of materials; enhanced inspection, abatement and enforcement activities; regulatory changes to clarify requirements and encourage proper management and recycling, while maintaining environmental protection; and the phasing out of other 
waste management activities such as deep well disposal of hazardous wastes and the use of landforms to treat and dispose of hazardous wastes.

\subsection{Canada US Agreement}

Each year, millions of tones of wastes are generated in Canada as by-products of industrial activities. About six million tones of these wastes contain toxic chemicals such as acids, phenols, arsenic, lead and mercury. Although it may be impossible to eliminate hazardous wastes entirely, efforts are being made to minimize their generation. Those wastes that remain are disposed of through a variety of methods intended to reduce environmental and human health risks. Ideally, hazardous wastes are recycled into other non-hazardous products or compounds so that valuable resources can be re-used. Other hazardous wastes are either disposed of at the site where they were generated, or shipped elsewhere to be incinerated, detoxified by physical or chemical treatment, or disposed of ir a secure landfill site.

Canada and the United States both recognize the environmental and economic advantages of minimizing the distances that hazardous wastes must travel. As a result, approximately 900,000 tones of hazardous waste cross the Canada-U.S. border annually, on their way to the nearest environmentally sound recycling, treatment or disposal site. In order to lessen any threat to the environment or public safety during transportation, and to manage Trans boundary shipments effectively, Canada and the United States have entered into a comprehensive agreement. This agreement sets out specific administrative conditions for the export, import, and transportation of hazardous waste between the two countries. 
The Agreement between the Government of Canada and the Government of the United States of America Concerning the Trans boundary Movement of Hazardous Waste was signed by the Canadian Environment Minister and the U.S. Environmental Protection Agency Administrator on October 281986 and came into effect on November 8, 1986. The Agreement ensures both that the Trans boundary movement of hazardous waste is handled safely and that such waste is shipped to facilities that are authorized by the importing jurisdiction. Within the context of the Agreement, wastes are considered hazardous if defined as such by the legislation of the exporting country. In Canada, hazardous wastes are covered by the Export and Import of Hazardous Wastes Regulations.

\subsubsection{Compatibility with Basel Convention}

Article 11 of the United Nations Basel Convention on the Control of Trans boundary Movements of Hazardous Wastes and their Disposal allows countries to enter into bilateral/multilateral agreements or arrangements, as long as these agreements or arrangements do not derogate from environmentally sound management of wastes. The Canada-U.S.A. Agreement, together with its supporting regulatory framework, is entirely compatible with the control procedures under the Basel Convention. The Agreement affirms the four basic principles that both countries recognize as necessary to control Trans boundary shipments of hazardous waste:

- Each country must adequately manage waste within its own jurisdiction. 
- The exporting country must give the importing country prior notice of the proposed shipment; the importing country then indicates whether it objects to the proposed shipment.

- The two countries must co-operate to ensure that Trans boundary shipments of hazardous waste are accompanied by proper manifests, in order to verify compliance with the Agreement and domestic regulations; and

- The exporting country must permit re-entry of any hazardous waste that may be returned by the importing country.

Hazardous waste generators and parties wishing to transport hazardous waste across the border must first submit, together with other relevant documents, a notice that contains a variety of detailed information about the proposed shipment including:

- The type and amount of wåste.

- When the waste will be exported.

- The name of the transporter and the method of transportation (air, highway, rail, water).

- The type of container used (drums, boxes, tanks, etc.).

- The name and address of the party to whom the waste will be shipped; and

- The method of recycling, treatment, storage, or disposal.

The notice is submitted to the designated authority in the exporting country, which notifies the designated authority in the importing country (Environment Canada or the U.S. EPA) of the proposed shipment. For imports into Canada, Environment Canada forwards the notice for review to the appropriate environmental authorities in the 
province to which waste will be shipped. Each province has jurisdiction over hazardous waste management within its borders.

After acknowledging receipt of the notice, the importing country has 30 days to review the request and indicate its objection or consent to the proposed shipment. The importing country has the right to alter the conditions of transport as described in the notice. Responses to the notice are then provided to the designated authority in the exporting country. If no response is received within the 30-day period, the importing country is considered to have no objections to the shipment. 


\section{CHAPTER 4}

\section{EVOLUTION OF THE BASEL CONVENTION}

\subsection{Introduction}

Before 1970s industries were just disposing hazardous waste by either burying them underground or sending the liquid waste into river and ponds, which in effect polluted several rivers, streams and seashores. The gasoline drums, for instance, which were buried underground, leaked and contaminated groundwater. When communities started complaining about the quality of water then several studies were made and finally the hazardous waste control laws were brought to legislation. Basel convention was not only implemented to regulate the hazardous waste transport but also to standardize disposal methods worldwide. This chapter presents background, implementation, importance, and milestones of the Basel convention.

\subsection{Background of Basel Convention}

In recent decades the problem of hazardous waste has grown considerably. In 1947, the worldwide generation of waste was about 5 million metric tons (Environment Canada 2001). By 1988, that figure had grown to over 300 million metric tons, with more than three-quarters of that, 265 million metric tons, coming from the United States alone (Environment Canada 2001). Disposal of hazardous waste has become a major concern to both developed and developing countries. Over the past few decades, developed nations have increasingly opted to ship their waste to developing countries. It was believed by both sides that agreeing on proper disposal methods was mutually 
beneficial from an economic standpoint; the developed world could dispose of its waste at a lower cost, while developing countries would benefit from the substantial revenue generated by waste disposal. Unfortunately, developing countries were often illequipped to dispose of the waste properly, leading to considerable environmental damage.

Developing countries, desperate for hard currency, were also concerned that the garbage of the first world was destroying their environment. A compromise solution was needed to deal with the massive amount of hazardous waste generated every year. In late 80 s when developed nations became aware of dangers of hazardous wastes they started making their laws tight and stringent. This "problem" for industries led these "toxic traders" search for cheaper ways to dispose of the hazardous wastes. These countries started dumping their hazardous wastes in poor developing and Eastern Europe nations.

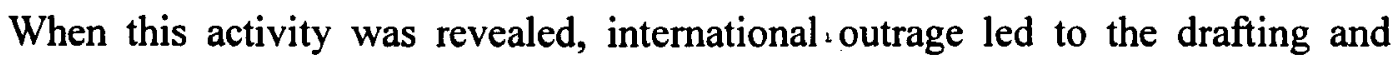
adoption of the Basel Convention. The Basel Convention on the control of Trans boundary Movements of Hazardous Wastes and their disposal was adopted in Basel, Switzerland on 22 March 1989. The Convention was initiated in response to numerous international scandals regarding hazardous waste trafficking that began to occur in the late 1980s. The Convention entered into force on 5 May 1992 and today has its Secretariat in Geneva, Switzerland.

\subsection{Implementation of Basel Convention}

During its first decade (1989-1999), the Convention was principally devoted to setting up a framework for controlling the "Trans boundary" movements of hazardous 
wastes, that is, the movement of hazardous wastes across international frontiers. It also developed the criteria for "environmentally sound management". A Control System, based on prior written notification, was also put into place.

The United Nations Environment Programme (UNEP) in 1987 took the first step toward a solution to the world's waste disposal problems. It adopted the Cairo Guidelines and Principles for the Environmentally Sound Management of Hazardous Waste, which contained recommendations concerning the export of hazardous waste. The Cairo Guidelines call for "notification to receiving and transit nations of any export and consent by those nations prior to export." . Under these guidelines, it is the exporter's responsibility to ensure that the disposal site meets specified requirements for safety. UNEP wanted to enlarge the scope of their international regulation of hazardous waste by creating a convention to formalize regulation procedures into international law.

The Basel Convention, signed by 116 nations, was the result of this effort. Signed in Budapest, Hungary in October 1987, the Convention went into force on May 5, 1992. The debate over the scope of the Convention caused many delays in the negotiating process. Some nations wanted an outright ban on the Trans boundary movement of wastes, while others sought only minimal regulation. In the end, the Basel Convention produced twenty-nine articles and six annexes that regulate, from cradle to grave, all hazardous wastes that are to be shipped across national borders.

Before the Convention could set down regulations for hazardous waste, a mutually agreeable definition for waste had to be reached. The final version allowed for the definition of hazardous waste to come from provisions written into the national laws of the signatories; thus, the definition was not universal but country based. In addition, 
wastes were defined according to their origins and component parts. The incorporation of national laws into the definition of waste products helped foster consensus among the signatories (United Nations Environment Program 1989).

The Basel Convention also called for signatories to work to reduce the amount of hazardous waste that they generate. There were no provisions for how much, or in what time frame, waste generation should be reduced, thus mitigating much of the provision's effectiveness. However, it did note that any waste that cannot be properly disposed abroad should be disposed of as close as possible to the source of production and done in an environmentally safe manner.

\subsection{Importance of Basel Convention}

The regulation of the international shipment of hazardous waste was the real goal of the Basel Convention. Regulation of waste origins and destinations is important to ensuring products are disposed of in an environmentally sound way. The regulation procedure is as follows: the exporting nation must notify in advance the importing nation of the nature of the waste to be trans-shipped. Proper disposal sites are then to be guaranteed by the exporter. The receiving nation and any intermediate nations may deny entry, request additional information, or approve the shipment. A type of uniform consignment note, listing contents, hazards, and disposal procedures, must accompany waste shipments at all times. The disposer must notify the exporter and the exporting nation once disposal of the waste is complete. To prevent any country from circumventing the provisions, signatories are forbidden to export waste to non-signatory 
nations unless it is done under the provisions of a separate bilateral or multilateral agreement.

Based on the background and implementation of the Basel Convention it is concluded that this is in fact a very good program. The Convention Report has goals to control the hazardous waste in a very secure way. Their program is not for the present but it is also for the future. During The Next Decade (2000-2010), the Convention will build on this framework by emphasizing full implementation and enforcement of treaty commitments. The other area of focus will be the minimization of hazardous waste generation. Ministers meeting held at Basel in December of 1999 set out guidelines for the Convention's activities during the next decade, including:

- Active promotion and use of cleaner technologies and production methods.

- Further reduction of the movement of hazardous and other wastes.

- The prevention and monitoring of illegal traffic.

- Improvement of institutional and technical capabilities, through technology when appropriate especially for developing countries and countries with economies in transition.

- Further development of regional and sub regional centers for training and technology transfer.

\subsection{The Vital Goal of Basel Convention}

The main goal of the Basel Convention is "environmentally sounds management" (ESM), the aim of which is to protect human health and the environment by minimizing hazardous waste production whenever possible. ESM means addressing the issue through 
an "integrated life-cycle approach", which involves strong controls from the generation of a hazardous waste to its storage, transport, treatment, reuse, recycling, recovery and final disposal.

Many companies have already demonstrated that "cleaner production" methods, which eliminate or reduce hazardous outputs, can be both economically and environmentally efficient. The United Nations Environment Program's (UNEP) Division on Technology, Industry and Economics works to identify and disseminate "best practices". Please refer to their site, which again shows their hard work to control the hazardous waste problems (United Nations Environment Program 2001).

In the coming decade, more emphasis will be placed on creating partnerships with industry and research institutions to create innovative approaches to ESM. One of the most critical aspects of ESM is lowering demand for products and services that result in hazardous by-products. Consumers need to educate themselves as to the methods used in production processes and think about what they buy every day.

\subsection{An Overview of Compliance and Enforcement}

The Basel Convention contains specific provisions for the monitoring of implementation and compliance. A number of articles in the Convention oblige Parties (national governments which have acceded to the Convention) to take appropriate measures to implement and enforce its provisions, including measures to prevent and punish conduct in contravention of the Convention. 


\subsubsection{The Control System for the Movement of Hazardous Waste}

Because hazardous wastes pose such a potential threat to human health and the environment, one of the guiding principles of the Basel Convention is that, in order to minimize the threat, hazardous wastes should be dealt with as close to where they are produced as possible. Therefore, under the Convention, Trans boundary movements of hazardous wastes or other wastes can take place only upon prior written notification by the State of export to the competent authorities of the States of import and transit (if appropriate). Each shipment of hazardous waste or other waste must be accompanied by a movement document from the point at which a Trans boundary movement begins to the point of disposal. Hazardous waste shipments made without such documents are illegal. In addition, there are outright bans on the export of these wastes to certain countries. Trans boundary movements can take place, however, if the state of export does not have the capability of managing or disposing of the hazardous waste in an environmentally sound manner.

\subsubsection{National Reporting of Hazardous Wastes}

Each country that is a Party to the Convention is required to report information on the generation and movement of hazardous wastes. Every year, a questionnaire is sent out to member countries, requesting information on the generation, export and import of hazardous wastes covered by the Convention. This information is reviewed and compiled by the Secretariat and is presented in an annual report, which includes statistical tables and graphic representations of the data (United Nations Environment Program 2001). 


\subsubsection{Technical Assistance Offered by the Convention}

In order to assist countries (as well as interested organizations, private companies, industry associations and other stakeholders) to manage or dispose of their wastes in an environmentally sound way, the Secretariat cooperates with national authorities in developing national legislation, setting up inventories of hazardous wastes, strengthening national institutions, assessing the hazardous waste management situation, and preparing hazardous waste management plans and policy tools. It also provides legal and technical advice to countries in order to solve specific problems related to the control and management of hazardous wastes. In the case of an emergency, such as a hazardous waste spill, the Secretariat cooperates with Parties and relevant international organizations to provide rapid assistance in the form of expertise and equipment.

\subsubsection{Training in the Management and Minimization of Hazardous Wastes}

An integral part of implementing the Basel Convention is building the capability to manage and dispose of hazardous waste. Through training and technology transfer, developing countries and countries with economies in transition gain the skills and tools necessary to properly manage their hazardous wastes. To this end, the Basel Convention has established Regional Centers for Training and Technology Transfer in the following countries: Argentina, China, Egypt, El Salvador, India, Indonesia, Nigeria, Senegal, Slovak Republic, South Africa, Russian Federation, Trinidad \& Tobago and Uruguay.

The role of the centers is to help countries implement the Basel Convention. Important activities include providing guidance on technical and technological issues as 
well as advice on enforcement aspects of the Convention. The Centers also encourage the introduction of cleaner production technologies and the use of environmentally sound waste management practices.

\subsection{Milestones in the Convention's History}

1999 Protocol on Liability and Compensation - The Protocol on Liability and Compensation, adopted in December 1999, established rules on liability and compensation for damages caused by accidental spills of hazardous waste during export, import or during disposal.

1999 Ministerial Declaration - The Basel Declaration, also adopted at COP-5 meeting, set out the agenda for the next decade, with a special emphasis on minimizing hazardous waste (United Nation Environment Programme 2001).

1998 Classification and Characterizations of Wastes - The Technical Working Group of the Basel Convention agreed on lists of specific wastes characterized as hazardous or not -hazardous. These lists were later adopted by the Parties to the Convention, thereby clarifying the scope of the Convention.

1995 Ban Amendment - The Amendment calls for prohibiting exports of hazardous wastes (for any purpose) from countries listed in a proposed new annex to the Convention (Annex VIII - Parties that are members of the EU, OECD, Liechtenstein) to all other Parties to the Convention. In order to enter into force, the Ban amendment has to be ratitied by 62 of the Parties present at the time of adoption. 
1992 Basel Convention enters into force.

1989 Adoption - After a public outcry against the indiscriminate dumping of hazardous wastes in developing countries by developed-world industries, a diplomatic conference held in Basel, Switzerland, adopted the Convention. 


\section{CHAPTER 5}

\section{HZARDOUS WASTE TRANSPORTATION}

\subsection{Introduction}

There are regulations and proper management's practices to manage and regulate the hazardous waste transportation. But there still risk involved during their transportation. The ultimate risk is for the human. Therefore, certain techniques and advance technologies are used to ensure safety of the hazardous wastes transport. Three modes of transport: motor carrier, rail carrier, and water carrier are used for the transportation of hazardous waste materials. Different models for the risk analysis and highway routing are developed (Douglas et al. 1990, Chung-Kuo 1990). This chapter presents modes of transport, developed models, and advance technologies used for the hazardous wastes transportation.

\subsection{Modes of Transportation}

Ensuring a safe transportation of hazardous materials is a complex activity. The accidental release of hazardous materials poses serious threats to human safety and property and to the environment. During transportation, classification of hazardous substance affects packaging, marking, labeling, and placarding. Each transportation department has list of transported material in their regulations. Shippers follow the required packing given in the regulation. If the material is not listed, however, the shipper must determine if it is hazardous or not and classify it according to the universal definitions in the regulations. 
Hazardous wastes are often accumulated in drums and containers. Historically, these waste drums have been stored to eventually corrode and pose a threat to human health and the environment. EPA has drum and container regulations to better manage industry practices in handling hazardous wastes. Under these regulations, all hazardous wastes must be placed in drums and containers that are good in conditions. The hazardous wastes must be compatible with the drum and container. Inspections must be periodically carried out to assess containers being used to store the hazardous wastes. Any wastes in the drum that are either damaged or leaking must be recontainerized. The drum reconditioning industry uses the hazardous waste industry as a potential source of drums, but there is a long-term risk in supplying used drums to reconditioners (Charles 1989). The modes of transport are discussed in the following sections.

\subsubsection{Highway Transport}

Cargo tanks are the main carriers of bulk hazardous materials over the roads. Cargo tanks are usually made of steel or aluminum alloy but can be constructed of other materials, such as titanium, nickel or stainless steel. They range in capacity from about 4000 to 12,000 gallons. Federal road weight laws usually limit motor vehicle weights to 80,000 pound gross. Some States, however, allow higher weights, and in those states cargo tanks can have capacities larger than 112,000 gallons.

The bulk trucking business differs from rail or water bulk transport in that there are many more small carriers, including interstate and intrastate carriers. The quality of the equipment varies within each of these groups, but generally the large private interstate tankers have newest tankers. And the small private carriers have the older equipment. 
Many of the most serious discharges of hazardous wastes during bulk transport over the highway are caused by vehicle accidents, the result of driver error and/or equipment failure. Both improving equipment safety and providing driver training could thus reduce the number of accidents. Various hazardous material transportation regulations and motor carrier safety regulation parts govern the trucking industry.

Basel Convention Regulation subpart A of part 173 requirements include: Compliance with Federal Motor Carrier Safety Regulations, State and local laws, ordinance and regulations, Attendance and surveillance of motor vehicles, Parking, Routes, Fires, Smoking, Fuelling, Tires, Instructions and documents, and Marking of vehicles operated by private carriers. According to Hazardous Materials Transportation Regulations (HMTR) under 49 Code of Federal Regulations (CFR) part 177, motor carriers may accept for transportation only those shipments prepared in accordance with the marking, labeling and placarding requirements under CFR Part 172 (Arthur 1990).

\subsubsection{Rail Transport}

Rail shipment account for about 5 percent of the tonnage of hazardous wastes Iransported annually. All rail containers must be of the proper specification, regardless of the origin, destination, or duration of the trip or characteristics of the shipper or carrier. About $80 \%$ of hazardous materials involve tank cars, which have useful lives of 30 to 40 years. With regard to the transportation of hazardous materials/wastes by rail, the HMTR require that shipments be prepared in accordance with parts 171,172 and 173 of Title 49 CFR before acceptance by any carrier. Before accepting a shipment of hazardous material/wastes for transport, each carrier must also: Obtain the proper shipping paper 
manifest from the shipper and inspect the shipment to make sure it conforms to the shipping paper/manifest. Carriers transporting by rail are also required to forward shipments to destinations specified as quickly as possible.

\subsubsection{Water Transport}

The largest bulk containers for water transport are ships, tankers, and tank barrages; together they account for about $91 \%$ of all marine shipping of hazardous material/wastes. Tank barges range in capacity from 30,000 to 600,000 gallons, and tankers can be 10 times larger. Marine shipments typically involve very large quantities, and fewer trips are required to move a given amount of product by water than by the other modes. Bulk marine shippers and recipients of product by water than by other modes. Bulk marine shippers and recipients are generally large companies, well aware of the potential liability they assume with each shipment. Because of the substantial economic investment these shipments represent, the companies expend the necessary resources to ensure safe transport. In addition, the vessels travel slowly. For all these reasons, the water is statistically the safest, both in absolute numbers of accidents and spills per-ton-mile. Although when a spill does occur, the damage is enormous.

All vessels carrying bulk hazardous materials/wastes are subject to Federal regulations. Records kept by the government list every vessel in commerce in US water. The coast guard also regulates tank barges and tankers. All new vessels to be used to transport bulk hazardous cargoes must meet the design requirements of 46 and 49 CFR. Shipments of hazardous materials/wastes being transported by vessel must be accompanied by the proper shipping paper/manifest. The proper DOT shipping name, the 
hazard classification, and the total quantity of the material/waste being shipped must appear on the paper.

\subsubsection{Air Transport}

Because the amount of hazardous waste transported by air is quite small, specific industry knowledge about such transport is very limited. Hazardous waste transport by air is extremely limited due to its expense, but the amount of all hazardous materials shipped by air is small. Samples of hazardous waste are sometimes air-shipped to disposal facilities for laboratory analysis prior to transporting the bulk wastes for disposal.

The existing regulations and standards for the transport of hazardous materials by air are much more stringent than those for other modes. For passenger aircraft, the only allowable hazardous materials are certain radioactive materials, dry ice, liquid nitrogen, magnetized materials and more ecological agents. Flammable liquids, irritants and corrosive materials are restricted to one-quart containers. Container drums of hazardous malerials are no longer required (Arthur 1990).

\subsubsection{Pipeline Transport}

In general, pipeline transport in USA is extremely limited. Pipeline companies that transport crude oil or other raw material or product does not carry hazardous waste for several reasons: Most pipelines are not designed for hazardous waste transport, It is impractical and uneconomical to transport both types of materials (waste and products), and existing pipelines, being stationary, don't ordinarily link hazardous waste generators to treatment, storage or disposal facilities. Thus, hazardous waste transport by pipeline is 
confined to a few concentrated industrial areas in the USA. Pipelining of waste may be economically attractive where a disposal site is located in the midst of a heavy industrialized area.

\subsection{Risk Management in Hazardous Waste Transport}

There are many formulas to describe the concept of risks. The most common is the probability of an unwanted event weighted by the consequences of that event. For hazardous wastes, the unwanted event is the accident release of the product; the consequences of an uncontrolled release (both potential and real) are the effects of the nature of the danger or hazard posed (i.e. flammability, toxicity) in terms of damages and losses incurred. During transport the risk may be even more pronounced due to uncertainty of not only when, but also where an accident release of product may occur. The only assurance of achieving zero risk for the transport of hazardous wastes is to reduce on of the two components, probability or consequence, to zero. Reducing the probability of a transportation accident to zero requires prohibition of the movement (Marjorie 1990).

Eugene (1990) conducted a study in Kansas State University to develop a methodology for developing high-risk scenarios and counter measure ideas. The study developed a set of prioritized, extreme-risk scenarios, a set of feasible, practical, and implementable protective systems. Eugene (1990) also summarized the guidelines on the use of these protective systems to mitigate potential, extreme-risk situations that could occur during the transport of hazardous materials (hazmat) on our highway system. The study came up with only one type of protective system that could be called "preventive", 
that was found to be most effective. This type consists of various barriers to contain a hazmat vehicle on or within the roadway to prevent it going off an overhead facility, off a ramp, into a schoolyard, etc. Various types of barrier rail designed to contain large trucks would be typical of this category.

Richard (1990) discussed the evolution and current status of the Hazardous Materials Incident Report System (HMIRS) that is maintained by the Research and Special Programs Administration (RSPA) of the U.S Department of Transportation (DOT). The basis for study was to review the collected information by Federal on hazardous materials incidents, and to improve the collection and use of incident information. Richard (1990) presents the results of a survey of connective fire chiefs and discusses how their perceptions of risk affect their attitudes towards risk preparedness and risk management practices. The results indicate that support for the hazmat transport system is a function of risk perception, population size, and low ratings of system effectiveness. Public especially nearby residents who may be exposed to highway spills involving gasoline, propane or sulfuric acid encourages fire chiefs to support more aggressive intervention on the part of local governments. Fire chiefs also favored restricted routing if they deem the current regulatory system to be relatively ineffective and if population size is taken into account.

The ultimate goal of any risk management information system (RMIS) is to provide a tool for reducing uncertainty in decision-making ensuring that decision is not made in ignorance. Douglas et al. (1990) developed a computerized model, which local jurisdictions can pursue to manage the risks related to hazardous waste transportation. The model was developed as a part of the first risk assessment. It contains several data 
banks and analytical components, including route-specific accident rates, conditional spill probabilities for different types of containers, and estimated consequences if an accidental release occur. Subsequent risk assessments are then built into the same model. The overall model and data can be revised as required to account for changes in the transport system over time. The model can be used to estimate the risk associated with various transportation modes, various transportation routes, and various hazardous materials. Based on the results of the model route restrictions, route improvements, and procedural and technological improvements policies can be improved for the safe movement of hazardous materials.

Chung-Kuo (1990) developed a model to assess the safety of a community through which hazardous material will be transported. The model is predictive and can be used even thee is no past data of incidents in that area. It draws on selective measure for both risk and community preparedness to meet that risk. Risk measure includes various characteristics of drivers, vehicles, and roadways, and the exposure of population and property. The proposed model is developed with two sub-models. First is community risk (CR) such as the likelihood of an incident (fire, spillage, or explosion) and the relative exposure to death, injury, or property damage. Second is community preparedness (CP), emergency response capability and preparedness, such as personnel, equipment, public awareness, and evacuation plans. The model is,

$$
L O S=C P / C R
$$

Where, LOS $=$ Community Level of Safety (Ranges from A to F), CP = Community Preparedness Level Index (Values from 1 to 100 ) and $C R=$ Community Risk Level Index (Values from 0.1 to 1.0$)$. 
The model for CR focus on roadway transportation (where 90 percent of hazardous materials accidents occur), but its methodology can be adapted for other transport modes (Chung-Kuo 1990). The evaluation of community risk model is based on three elements within some defined project area (often a half-mile to either side of a transportation corridor): the risk of a motor vehicle accident, the risk that such an accident will involve a carrier of hazardous materials, and the community exposure. The community risk (CR) is modeled as,

$$
C R=R_{L}(H M V) x\left(P_{D}+P_{V}+N_{E}+N_{S}\right) \times T_{F}
$$

Where,

$\mathbf{R}_{\mathbf{L}}(\mathrm{HMV})=$ Risk level index of an incident involving a motor vehicle carrying hazardous materials

$P_{D}=$ Population density factor

$\mathrm{P}_{\mathrm{V}}=$ Property value factor

$\mathrm{N}_{\mathrm{E}}=$ Condition and number of hazardous materials establishments

$\mathrm{N}_{\mathrm{S}}=$ Type and numbers of sensitive facilities (schools, hospitals, etc., in the vicinity of transport routes)

$T_{F}=$ Forms of threat resulting from an incident: fire, spillage, explosion, or combination $\mathrm{R}_{\mathrm{L}}$ (HMV) is separately modeled as sub-model as,

$$
R_{L}(H M V)=R L(M V) x\left(P_{E X}+P_{C G}+P_{F L}+P_{F S}+P_{O}+P_{P}+P_{C}+P_{M}\right)
$$

Where,

$\mathrm{P}_{\mathrm{EX}}=\%$ Explosives vehicles in ADT

$\mathrm{P}_{\mathrm{CG}}=\%$ Compressed gas vehicles in ADT

$\mathrm{P}_{\mathrm{FL}}=\%$ Flammable liquid vehicles in $\mathrm{ADT}$ 
$\mathrm{P}_{\mathrm{FS}}=\%$ Oxidizers and organic peroxides vehicles in ADT

$\mathrm{P}_{\mathrm{O}}=\%$ Poison vehicles in $\mathrm{ADT}$

$P_{P}=\%$ Radioactive vehicles in ADT

$\mathrm{P}_{\mathrm{C}}=\%$ Corrosive vehicles in ADT

$P_{M}=\%$ Miscellaneous or unknown class vehicles in ADT

$\mathrm{RL}(\mathrm{MV})=$ Risk level of index of a motor vehicle incident. (Converted to values 1 to 10$)$

$\mathrm{RL}(\mathrm{MV})$ is also modeled in sub-model as,

$$
R L(M V)=T_{L} x\left(D_{L}+V_{L}+R_{L}\right) \times S_{L}
$$

$T_{L}=$ Traffic volume level index

$\mathrm{D}_{\mathrm{L}}=$ Driver level index

$\mathrm{V}_{\mathrm{L}}=$ Vehicle level index

$\mathrm{R}_{\mathrm{L}}=$ Roadway geometry/environment level index

$\mathrm{S}_{\mathrm{L}}=$ Average vehicle speed level index

Traffic volume $T_{L}$ is rated 1 to 10 .

The second sub-model for community preparedness (CP) was seen as the sum of the emergency response capability index (ER) and the regulation compliance index $(R C)$ as,

$$
C P=E R+R C
$$

Where, $\mathrm{CP}=$ Community preparedness level index, $\mathrm{ER}=$ emergency response capability index (0-50), $\mathrm{RC}=$ regulation compliance index $(0-50)$.

\subsection{GIS and Transportation}

Geographic Information System (GIS) represents a technology with considerable potential for important application in transportation engineering. GIS is a computerized 
database management system for the capture, storage, retrieval, analysis and display of spatial data. A GIS contains two broad classifications of information: geocoded spatial data and attribute data. Geocoded data defines objects that have an orientation and relationship in two or three-dimensional space. Each object is classified as a point (such as an accident or a signal location), a line (for example highway), or polygon (number of people living within a block) and is tied to a geographic coordinate system. These objects have precise definitions and are clearly related to each other according to the rules of mathematical topology. Moreover, a GIS contains the same attribute data that are found in traditional databases. Attributes associated with a street segment might include its width, number of lanes, construction history, pavement conditions, and traffic volumes (Simkowitz 1989).

\subsubsection{GIS Applications in Routing Planning}

GIS is a powerful technology in the analysis and design of transport routing networks. The key contribution of GIS technology is that it adds a major degree of intelligence and sophistication to a transportation database that is inherently geographical in nature. The interaction between the transportation system and its surrounding environment makes GIS technology ideally suited for solid and hazardous waste routing design, risk analysis, and decision-making. GIS technology combines information on the transport network configuration, social and demographic factors, weather conditions, topography, and geology to assess the likelihood of a hazardous spill and its probable consequences. GIS can also be integrated with sophisticated mathematical options and policies (Hadi et al. 1995). 
GIS graphical display capabilities allow not only visualization of the different routes but also the sequence in which they are built, which allows the understanding of the logic behind the routing network design. For a segment on a road, a GIS system knows what routes cross it and whether there is an actual physical intersection. It knows the position of roadside features along the segment and can tell which census block are to the right and to the left of the segment within any distance of it. Rather than being limited to textual queries, it is possible to perform geographical queries in a straightforward, intuitive fashion. For example, a GIS with the appropriate routing algorithm and data can easily compute and display the route that will result in the minimum population exposure to a shipment of hazardous material. With the route drawn on the computer screen, the analyst can see immediately how the logic of the model has bypassed certain population centers. The analyst can create a detour by pointing to a road segment and deleting it from the network and then watching the routing algorithm redraw the path.

\subsubsection{GIS Risk Analysis of Hazardous Materials Transport}

GIS has been used in the risk analysis of hazardous materials transportation in Arizona. The main objective of that research was to assess the risk and vulnerability of transporting hazardous materials and wastes on the Arizona Highway System. A general GIS called Geographic Information Management System (GIMS) were used. The risk assessment model used was based on four factors: accident rate by segment, shipment frequency by highway segment, population density along the routes, and response time. Each component was evaluated and presented on the GIS map (Charles and James 1990). 
Although this study was one of the earliest and most basic research studies in this area, it lacks a strong modeling of risk assessments and routing evaluations.

The data were entered in Geographic Information Management System (GIMS). GIMS is a comprehensive vector and raster based system conceived, applied, and evolved in over 100 geographic analysis projects during the last 15 years. Five models were constructed based on the generic evaluation of four spatially varying components (Charles and James 1990). The components were accident rate, shipment frequency, population affected, and response time and their respective evaluations were incident probability, hazard, risk, and vulnerability respectively. The generic formula (Charles and James 1990) for the evaluation consisted of the following,

$$
\begin{aligned}
& \text { Absolute hazard }=(R)(F)^{\prime} \\
& \text { Population at risk }=(R)(F)(P) \\
& \text { Vulnerability }=(R)(F)(P)(T)
\end{aligned}
$$

Where,

$\mathrm{R}$ - Accident rate by sub-segment, these data are drawn directly from the accident rate iable

$f$ Shipment frequency by highway segment, these data are drawn from the previous survey data.

1. Population affected, determined by nearness of fire stations as modeled over the principal highway network. 


\subsection{Use of Advanced Technologies for Improving Hazmat Transportation Safety}

The transportation industry is undergoing major change. The "information age" promises to have a dramatic impact on the way transportation function is being performed today and is likely to be performed in the future. Over the past few years, a variety of new products and services have been available, and more are being developed each year. These products and services reduce the capital and manpower requirements of the transportation infrastructure, and improve the quality and safety of transportation.

These developments are particularly significant to the transportation of hazardous materials/wastes. As a society we are becoming increasingly aware of the risk involved in hazardous waste/material transportation. We want to protect lives and property, as well as our environment, and as we exercise tighter control on the movement of hazardous waste/material, we can use all the help we can get. Advanced technologies provide such help.

However, we need to recognize that advanced technologies are not the answer to all of the problems, because transportation safety can be enhanced through operational improvements as well. For example, improved routing, greater control over the allowable time of travel, and better training can also reduce risk significantly. In these instances, technologies play more of the complementary role.

The risks involved in the transportation of hazardous waste/materials arise primarily from release of such materials caused by accidents. A whole chain of events takes place before people are exposed to the harmful effects of hazardous materials/wastes - i.e. the accident takes place, material is released, it spreads (or 
explodes) and people caught in the way. To combat this risk, the safety can be improved by,

- Reduce the likelihood of the accident

- Reduce the likelihood of a release in a given accident

- Reduce the likelihood of severe consequences given a release, or

- Reduce the likely impact on people given a consequence.

There are various ways in which advanced technologies can help reduce the likeliness of and accident. Some advanced technologies dealing with vehicle control, driver information system, driver/vehicle performance measurement and heavy truck detection are discussed as follows (Ashok 1990).

Vehicle Control: The technologies in this area assist the driver in controlling the vehicle. One of the more promising developments is a collisions avoidance system. This involves tracking a vehicle in front using radar or a laser. The distance between two vehicles and their relative speeds are measured. If an imminent collision is expected, the system can alert the driver or apply brakes automatically. Although these types of devices have been available for quite sometime but they have not been further improved to the point that both false positive and false negative indications are completely eliminated.

Driver Information Systems: A variety of technologies are being developed to improve the quality of information being provided to the driver. One major group of technologies relates to the informing the driver where he is in relationship to his objective. This requires finding the vehicle's location (In an absolute term), and superimposing this location on an electronic map to locate with respect to the destination. 
There are five technologies that fit into the category of automatic vehicle location (Ashok 1990).

- Dead-reckoning system: The orientation and distance traveled are monitored, and, given an initial position, the system can find the vehicle's current location.

- Ground-based radio-determination system: An example of this type is LORAN-C, which has been available for navigating in coastal waters for quite a few years, and is now available for navigation over land. This system is used extensively in services offered by firms such as Motorola, Geostar etc and employs the principle of triangulation.

- Low-earth orbit satellite-based system: The technology used in this category is Global Positioning Systems (GPS/Navigator). Radio determination satellite systems (RDAA) these systems use distance from two satellites in geosynchronous orbit to determine location.

- Proximity system: In this system, fixed devices en route are used to determine the location of trucks carrying transporters (often called tags). The readers can be mounted on signposts, traffic lights or in the ground. The only problems with such a system are that the location is known only at the points where readers are located.

- Driver/Vehicle Performance: The trucks can now be equipped with on-board computer/vehicle management system (OBC/VMS) to monitor the performance of trucks and drivers. Parameters such as hours on the road, vehicle speed, and time since last break can be measured and recorded. The vehicle maintenance parameters can also be measured and recorded if so desired. This information can 
be conveyed in real time to a dispatch center in order to monitor the performance of the driver/vehicle continuously.

- Heavy Truck Detection: One potential cause of unsafe operation is truck carrying more loads than it should. Such overweight trucks can be detected using a weigh-in-motion (WIM) system. This system is installed in pavement. In most cases WIM is installed together with an automatic vehicle classification (AVC) system. The two systems working together cannot only weigh a truck but classify it and determine if the truck can operate safely on a bridge (Ashok 1990).

The consequence of some types of hazardous waste/material spill can be kept to minimum if immediate and correct actions are taken. For this to happen, the driver may need to communicate immediately with his dispatcher or an emergency response center. Technologies that provide two-way communications can help under these circumstances. In order to make educated decisions on whether advanced technologies should be deployed or not, it helps first to quantify the potential benefits. Most of these technologies provide other benefits besides improving safety. The wide use of these technologies has reduced the dangers but has not eliminated it. 


\section{CHAPTER 6}

\section{CONCLUSIONS AND RECOMMENDATIONS}

\subsection{Conclusions}

The following conclusions are concluded based on literature review of hazardous waste transportation,

1- It is estimated that only 25 percent of people in the emergency response network have adequate training to meet a hazardous materials emergency (Terry 1990). Therefore, a registration fee should be fix for trucking firms involved in this industry for the sake of training and equipment of hazardous materials response teams. These funds can be distributed among the various localities in some proportion to the degree of risk their populations face from such transportation.

2- There is lack of centralized tracking system 2 for all en-route shipments of hazardous materials. This leads to the inability to timely identify the products involved in incidents, which is also one of the major problems of emergency responders. Major transportation routes can be shut down unnecessarily. Therefore, there is need to develop a centralized tracking system to provide information to emergency responders about the shipment involved in incident.

3- Hazardous wastes are real threat to human life both in developed and developing countries. Developed countries have stringent laws and penalty systems for the negligence of handling of hazardous waste. Unfortunately this is not the case in third world countries. In these countries, along with the lack of law enforcement there are no proper hazardous waste management systems. Therefore, United 
Nation should organize hazardous waste management system in developing countries. There is also need to establish emergency system to be control by local authorities to prevent and mitigate major hazardous waste accidents in the industrial sector, in transportation, and in storage of hazardous waste.

4- The effects of hazardous wastes can be very dangerous. The inhaling of hazardous wastes vapors can cause swelling of the respiratory tract, nausea, vomiting, diarrhea, and respiratory failure. Therefore, human resource reduction, developing of new technologies for on-site treatment and handling of hazardous should be emphasized.

5- Transportation routes to send hazardous wastes to the dumping site should be chosen very carefully. The distance from the generation to the hazardous waste treatment center should be 'minimized. Traffic modeling and studies should be made before employing those trucks on the highways to see the vulnerability of innocent people. Risk assessment should be made carefully. The emergency response team in the case of accidents should consist of well-prepared and trained people. The response time should be minimized.

6- Use of the latest technologies is very effective in reducing accident risk during transportation of hazardous waste materials. But still it is required to develop models for different scenarios and evaluate the effectiveness of various technologies. Intelligent transportation system (ITS) can be used effectively for safe movement of hazardous waste transportation. The devices can be for automated information of accident notification to local emergency offices for immediate response of incident. 


\subsection{Recommendations}

1- There is need to improve the implementation of Basel Convention especially in third-world countries. The local regulations should be compatible with the Basel Convention. Some useful recommendations for the improvement of regulations are (United Nations Environment Programme 2001):

- The ports should have emergency response team to tackle the spillage in the sea if there is an accident or if ships get stuck in sand due to bad weather conditions.

- Ships that carry oil/hazardous wastes should not be more than 15 -year old. If somebody was found bypassing the law to save few bucks, this individual should be punished and the supporting department should be made liable to pay for the consequences.

- The shipping companies should also be held accountable if they use old ships to carry oil/hazardous wastes.

- The UN should force third-world countries to implement Environmental laws.

- Regular research should be made to evolve new technologies to avoid the accidents/spillage on highways/seas, at the generation plants and at the dumping sites.

- The fear of law has to be brought into the hearts of these company's officials who are involved in this trade.

- Learn from previous accidents and plans should be chalked out to avoid the scenario, which brought the disaster.

- Every company should have trained staff/ drivers who could immediately react in the case of accidents. 
- Illegal trade of hazardous wastes between the companies of developed countries and the underdeveloped country's pirates should be abolished.

- Some times the third world countries are made a dumping ground without even notifying those countries officials. These companies bribe the local people who live around the coastal belt. These multinational companies then dump hazardous wastes without any safety measures. If any company/individuals found doing that they should be penalized heavily and asked to clean up the mess, which they created without following environmental laws.

2- New simulation models should be developed for the simulation of hazardous waste materials transportation. There are a lot of applications of simulation in this research area. The reconstruction of incidents and their possible impacts on the surrounding communities can be simulated to have an idea of possible measures.

3- The design of vehicles and ships used for the transportation of hazardous waste materials should be included in simulation models. This will help improve their design for the safe movement of transportation of hazardous wastes.

4. Accident models for hazardous waste transportation should be developed region wide considering local data of accidents and highway geometric design.

5. Routes for hazardous waste transportation should be designed in such manner that they should pass through corridors away from local communities. Since the main cause of accidents is speeding, the speeds of the vehicles carrying hazardous wastes should be restricted. If possible they should be assigned a specific lane and overtaking should be restricted. This requires the development of new traffic rules for hazardous waste transportations. 


\section{REFERENCES}

Ashok B. Boghani, 1990, "Use of Advanced Technologies for Improving Hazardous Waste Transportation Safety", Transportation of Hazardous Waste Materials, Proceedings of the National Conference on Hazardous Materials Transportation 1990. pp. 262-270.

Alaska Department of Environmental Conservation, 1986. Disposal Directory for Small Quantities of Hazardous Waste Prepared for the Municipality of Anchorage. Anchorage, Alaska.

Barry Johnson, 1999, "Impacts of Hazardous Waste on Human health " book edition 1999.

Arthur D Little, Inc, 1990, "Guidance manual Characterization of hazardous waste transportation and economic impact assessment of hazardous waste transportation regulations, EPA", EPA/DOT hazardous Waste Transportation Interface.

Arthur D Little, Inc, 1990, "Characterization of hazardous waste transportation and economic impact assessment of hazardous waste transportation regulations", Environmental Protection Agency.

Canadian Petroleum Association, 1984. Disposal Guidelines for the Petroleum Industry Prepared for the Environmental Planning and Management Committee.

Carpenter, Bill, 1990. Bowspringer Kennels and Veterinary Clinic Ltd. Personal Communication. Yellowknife, NWT.

Chung-Kuo Chiang, Edmund J. Cantilli, and Stephen T. Ying, 1990, " Assessing community safety for hazardous materials transport" Transportation of Hazardous Waste Materials, Proceedings of the National Conference on Hazardous Materials Transportation 1990. pp. 134-147. 
Canadian Council of Resources and Environment Ministers, 1986. "The PCB Story". Fact sheet. Toronto, Ontario.

Charles A Wentz, 1989, "Hazardous waste management" Transportation of Hazardous Waste Materials, Proceedings of the National Conference on Hazardous Materials Transportation 1990. pp. 104-119.

Charles Anders and James Olsten, 1990 "Risk analysis of Hazardous Materials Transport" Transportation of Hazardous Waste Materials, Proceedings of the National Conference on Hazardous Materials Transportation 1990. pp. 52-61.

Citizens Environmental Coalition, 1991, "Managing Medical Waste", Fact Sheet No. 6, Citizens Environmental Coalition, Albany, New York, 1991.

Deyle, Robert E., 1989. Hazardous Waste Management in Small Businesses: Regulating and Assisting the Smaller Generator Greenwood Press, Inc. Westport Connecticut.

Douglas K, Anthony, AICP and John Peirson 1990, "Managing Risks of Hazardous Materials Transportation in Santa Barbara Country "Transportation of Hazardous Waste Materials, Proceedings of the National Conference on Hazardous Materials Transportation 1990. pp. 120-133.

Environment Canada, 1988. "Household Hazardous Wastes." Fact Sheet. Edmonton, Alberta.

Environment Canada, 2001. "Hazardous Wastes Management in Canada." (http://www.ec.gc.ca/press/2002/020709-2_b_e.htm).

Environment Canada, 2001, "Transportation of Dangerous Goods Act \& Regulations, Federal Legislation." http://www.on.ec.gc.ca/pollution/fpd/hazwaste/intro-e.html. 
Eugene R. Russell, Sr, 1990, "Developing High-Risk scenarios and Countermeasure Ideas for Mitigation of Hazardous Materials Incidents" Transportation of Hazardous Waste Materials, Proceedings of the National Conference on Hazardous Materials Transportation 1990. pp. 38-51.

Heinke, G.W. and Jeff Wong, 1990. Solid Waste Composition Study for Iqualuit, Pangnirtung, and Broughton Island of the Northwest Territories Prepared for the Department of Municipal and Community Affairs, GNWT. Yellowknife, NWT.

Helfrick, Donald, 1990. Hazardous Waste Specialist, Department of Renewable Resources, Pollution Control Division, GNWT. Personal Communication. Yellowknife, NWT.

Lavalin Engineers Inc., 1984. Study to Develop a Uniform Strategy for Handling Solid Wastes in the Beaufort Region Prepared for Environmental Protection Service, Environment Canada. Yellowknife, NWT.

Ministry of Environment, Ontario, 2001, "Hazardous Waste Management in Ontario" http://www.ene.gov.on.ca/.

Marjorie K. Matthews 1990, "Risk Management in the Transportation of Dangerous Goods- the Influence of Public Perception" Transportation of Hazardous Waste Materials, Proceedings of the National Conference on Hazardous Materials Transportation 1990. pp. 34-37.

M Hadi Baaj, Suleiman Ashur, Miguel and David Pijawka, 1995, "Design of routing networks using GIS: Applications to solid and hazardous Transportation planning", Transportation research record No. 1497. pp. 140-144. 
Pruss A., Giroult E., Rushbrook P, 1999, "Safe Management of Wastes from Health-Care Activities", World Health organization, Geneva, 1999.

Richard C. Hannon, 1990, "Hazardous Materials Data: A Federal Perspective" Transportation of Hazardous Waste Materials, Proceedings of the National Conference on Hazardous Materials Transportation 1990. pp. 62-73.

Reid, Crowther and Partners Limited, 1980. Hazardous Wastes in Northern and Western Canada, Vol. I \& II Prepared for Environment Canada.

Rutala W.A., Mayhall C.G, 1993, "Control and Hospital Epidemiology", Society for Hospital Epidemiology of America, Printed in Leach Bisson, 1993.

Scanlon, Raymond D., 1987, "Hazardous Materials, Hazardous Waste: Local Management options." International City Management Association, Washington, D.C.

Strecher, Paul G., 1968. "The Merck Index, Eighth Ed." Merck and Company, Inc., Rahquay, N.J., USA.

Simkowitz H.J, 1990, "Adaptation of Geographic Information Systems to Highway management", Journal of Transportation Engineering, vol. 116, May/June 1990.

Stanley Associates Engineering Ltd., 1986. Waste Management in the North: A Discussion Paper Prepared for Indian and Northern Affairs Canada, Northern Environment Directorate. Hull, Quebec.

Stephen Paul, 1983 "Hazardous Waste Transportation" Wall Street Journal, March 1, 1983, pp. 72-80. 
Terry L. Novak, 1990, "Local Government Views Hazardous Materials Transport Legislation" Transportation of Hazardous Waste Materials, Proceedings of the National Conference on Hazardous Materials Transportation 1990. pp. 2-8.

Thompson, Neil, 1990. Department of Renewable Resources, Pollution Control Division, GNWT. Personal Communication. Yellowknife, NWT.

Technology Resources Inc., 1989. Hazardous Waste Management Practices for Small Quantity Generators in Canada Prepared for the B.C. Ministry of Environment. Vancouver, B.C.

United Nations Environment Programme 1989, "Basel Convention on the control of Trans boundary movements of hazardous wastes and their disposal adopted by the conference of the plenipotentiaries on 22 marches 1989. (http://www.basel.int/text/cone.htm).

United Nations Environment Programme 2001, "Goal of Basel Convention". http://www.unepie.org/.

United Nations Environment Programme 2001, "Reporting of Hazardous Wastes". http://www.basel.int/.

Wilson, David C. and Fritz Balkau, 1990. "Adapting Hazardous Waste Management to the Needs of Developing Countries. An Overview and Guide to Action." Waste Management and Research Vol. 8, pp. 87-97. 


\section{APPENDIX: A}

The following are the hazardous wastes along with their impact on human health (Scanlon 1987, Stecher 1968),

- Ammonia: A substance used for copying of blueprints. Inhalation of the concentrated vapours cause swelling of the respiratory tract, which can result in suffocation.

- Arsenic: A heavy metal, which is highly toxic in most forms. Swallowing can result in nausea, vomiting, and diarrhea that can progress to shock and death. Prolonged exposure to small concentrations can result in liver and kidney damage.

- Asbestos: A mineral fiber used as an insulating material. It can cause cancer or asbestosis if inhaled or swallowed.

- Barium: A substance that can be present in waste oil. All water-soluble or acidsoluble barium compounds are poisonous.

- Benzene: A solvent that may be a contaminant in waste oil. Exposure by swallowing or inhalation can cause irritation of mucous membranes, restlessness, convulsions, excitement, or depression. Death may follow from respiratory failure. Chronic exposure through skin contact may cause leukemia.

- Benzo-pyrene: A contaminant sometimes present in waste oil. It is a potential carcinogenic agent.

- Beryllium: A metal that can be hazardous to human health when inhaled. Death may result from relatively low exposures to extremely low concentrations of the element and its salts. It is discharged by machine shops, ceramic and propellant plants, and foundries.

- Cadmium: A heavy metal element that can accumulate in the environment. Ingestion can result in increased salivation, choking, vomiting, abdominal pain and diarrhea. Inhalation can result in throat dryness, coughing, headaches, vomiting, chest pains, and extreme restlessness and irritability.

- Caustic soda: Sodium hydroxide (Noah) is a strong alkaline substance used as the cleaning agent in some detergents. It is corrosive to all tissues. Ingestion may 
cause vomiting, and collapse. Inhalation of the dust or mist may cause damage to the respiratory tract.

- Chloroform: A solvent that is believed to cause cancer.

- Chromium: Chromium is a heavy metal that can cause skin irritation when contacted. Inhalation can cause nasal irritation. Violent intestinal irritation with vomiting and diarrhea result from swallowing the substance.

- Contact pesticide: A chemical that kills pests when it touches them, rather than by being eaten (stomach poison).

- Creosote: A substance commonly used as a wood preservative. Large doses may cause intestinal irritation, cardiovascular collapse and death.

- Dichlorodifluoromethane: A contaminant that may be present in waste oil. It has little toxic action but can form toxic substances when burned.

- DDT: The first chlorinated hydrocarbon insecticide (chemical name: 1, 1, 1traitorous 2, 2-bis ( $\mathrm{p}$ - chloroprene) -ethane.). It has a half-life of 15 years and can collect in fatty tissues of certain animals. Poisoning results from swallowing, skin contact or inhalation. Death occurs within $24 \mathrm{hrs}$ of receiving a fatal dose of $500 \mathrm{mg} / \mathrm{kg}$ body weight. Solvents such as kerosene increase its toxicity.

- Ethylene Glycol: This substance is used as antifreeze. When swallowed it can cause depression, vomiting drowsiness, fatigue, respiratory failure, and convulsions, which may proceed to death.

- Fluorocarbons: A gas used as a propellant in aerosols. They are believed to be modifying the ozone layer in the stratosphere thereby allowing more harmful solar radiation to reach the Earth's surface.

- Heavy Metals: Metallic elements such as mercury, chromium, cadmium, arsenic, and lead, with high molecular weights. They can damage living things at low concentrations and tend to accumulate in the food chain.

- High density polyethylene: A material used to make plastic bottles that produces toxic fumes when burned.

- Hydrocarbons: Compounds found in fossil fuels, which contain carbon and hydrogen and may be carcinogenic. 
- Hydrogen Sulphide $\left(\mathrm{H}_{2} \mathrm{~S}\right)$ : The gas emitted during organic decomposition that smells like rotten eggs. It is also a by-product of oil refining and burning. It is extremely hazardous and can cause collapse, fatigue or death from respiratory failure within a few seconds after inhalation. Headaches, dizziness and nausea may appear after exposure to low concentrations.

- Kerosene: A fuel used in lamps and stoves. Inhalation of high concentrations can cause headaches, drowsiness, and coma. Swallowing causes vomiting, and diarrhea.

- Lead: Lead is a heavy metal, which is a major contaminant in waste oil. It is also present in some paints. Acute exposure may result in permanent brain damage. Chronic lead poisoning can result in weight loss, weakness and anemia.

- Methyl Alcohol: Ingestion of this substance can result in poisoning; headaches fatigue nausea or complete blindness.

- Phenols: Organic compounds that are by-products of petroleum refining, tanning, textile, dye and resin manufacture. Low concentrations can cause taste and odour problems in water, higher concentration can kill aquatic life.

- Phosphates: Chemical compounds containing phosphorous. High concentrations in water bodies can stimulate the growth of algae causing depletion of oxygen in the water.

- Polyvinyl chloride: A commonly used plastic that releases hydrochloric acid when burned.

- Propane: A compound that may be present in discarded gas cylinders. It can be a narcotic at high concentrations.

- Sulphur dioxide $\left(\mathrm{SO}_{2}\right)$ : A heavy, pungent, colorless gas formed primarily by the combustion of fossil fuels. It may be intensely irritating to the eyes and respiratory tract.

- Sulphuric acid: The most commonly used acid in batteries. It is corrosive to all body tissues. Inhalation of concentrated vapor can cause serious lung damage. Contact with eyes may result in total loss of vision. Swallowing may cause severe injury and death. 
- Tetrachioroethylene: A solvent, which may be present in waste oil and considered to be the most toxic of the common chlorinated hydrocarbons. Poisoning can occur by inhalation, ingestion or skin contact. Symptoms are nausea, vomiting, diarrhea, headaches and liver and kidney damage.

- Toluene: This is a solvent that can be present in waste oil. It may cause anemia. It is a narcotic at high concentrations.

- 1,1,1-Trichloroethane: A solvent that may be present in waste oil. It is irritating to the eyes and mucous membranes and a narcotic at high concentrations.

- Trichloroethylene: This is a solvent which is sometimes used in dry-cleaning, and may be a contaminant in waste oil. It is a narcotic at high concentrations. Deaths have occurred after heavy exposures.

- Turpentine: A commonly used solvent that is irritating to the skin and mucous membranes. It can also cause severe kidney irritation.

- Vinyl chloride: A chemical compound used in producing some plastics. It may be a narcotic at high concentrations. It is also believed to be carcinogenic.

- Xylene: A solvent that may be a contaminant in used oil. It may be a narcotic in high concentrations.

- Zinc: A contaminant that may be present in waste oil. Inhalation can cause throat dryness, coughing, weakness, generalized aching, chills, fever, nausea, and vomiting. Ingestion may cause nausea, and vomiting.

- Mercury: Mercury can be present in some paints. It is a heavy metal, which can accumulate in the environment. Acute exposure to soluble mercury salts can cause violent corrosive effects on skin and mucous membranes, severe nausea, vomiting, abdominal pain, bloody diarrhea, kidney damage and death usually within 10 days.

- Methylene Chloride: Used as paint thinner. It can be a narcotic in high concentrations.

- Mineral Spirits: Also called petroleum spirits. Inhalation of high concentrations can cause headaches, drowsiness, and fatigue. Swallowing may causes vomiting and diarrhea. 
- Naphtha (Petroleum Benzin): Naphtha is a commonly used solvent. Inhalation of high concentrations can cause headaches, drowsiness, and coma.

- Naphthalene: Naphthalene is used in mothballs. It is also a contaminant in waste oil. Poisoning can occur from swallowing large doses, inhalation or skin adsorption. Symptoms are nausea, vomiting, headaches, fever, convulsions and fatigue.

- Nitric oxide (NO): A gas formed by combustion under high temperature and high pressure in a gas or diesel engine. It changes into nitrogen dioxide in the ambient air.

- Nitrogen dioxide (NO2): It is one of the most insidious gases. Exposure can cause inflammation of the lungs. This will only cause slight pain but the resulting tumor several days later may result in death. $100 \mathrm{ppm}$ is dangerous for even short exposures and $200 \mathrm{ppm}$ may be fatal.

- Ozone (03): A pungent, colorless, toxic gas. High concentrations cause severe irritation of the respiratory tract and eyes.

- PCB's (Polychlorinated biphenyls): A group of toxic, persistent chemicals used in transformers and capacitors. Extensive exposure can cause chloracne, a painful and disfiguring skin condition, similar to adolescent acne. Liver damage can also result. Brief exposures may cause skin rashes, swelling eyelids, headaches or vomiting. Long exposure to PCB's in animals can severely affect reproduction, and cause cancer (Canadian Council 1986).

- Pentachlorophenol (penta, PCP): This is commonly used as a wood preservative. It causes lung, liver, and kidney damage. It is more toxic in organic solvents.

- PERC (Perchioroethylene): A commonly used dry-cleaning substance. It is harmful to the liver and kidneys in humans if swallowed. It may also be carcinogenic.

- Persistent pesticides: Pesticides that do not break down chemically and remain in the environment after a growing season. 